\title{
Development and comparison of orally inhalable sustained release formulations for three respiratory drugs for asthma
}

\author{
K.Sathishkumar*, C.Kumaresan, R.Anantharaj \\ Department of Chemical Engineering, Sri Sivasubramaniya Nadar College of Engineering, Kalavakkam, \\ Kancheepuram - 603110, TN, India. \\ sathishkumark@ssn.edu.in
}

\begin{abstract}
The present work was designed to develop and compare orally inhalable sustained release formulation for salbutamol sulphate (SS), ambroxol hydrochloride (AH) and montelukast sodium (MS). The emulsion solvent evaporation method was used to prepare microparticles with the polymers. The prepared polymer encapsulated microparticles were blended with carrier inhalable lactose and filled in size 3 hard empty gelatin capsule. Formulations T1-T9 were prepared with 1:1 ratio of PLGA (50:50), PLGA (75:25) and Eudragit RS100. The formulation T1 prepared with SS:PLGA (50:50) produces best result when compared with other formulations T2-T9. Formulation T1 gives in vitro release $91.23 \%$ at $12 \mathrm{~h}$ and having particle size of microparticles $\left(D_{0.5} \mu \mathrm{m}\right) 1.94 \pm 0.6$ and respiratory fraction $34.9 \pm 2.59 \%$.
\end{abstract}

Key Words: Salbutamol, Ambroxol, Montelukast, Sustained release, Dry powder inhaler, Microparticles

\section{Academic Discipline And Sub-Disciplines}

Technical, Chemical sciences

\section{SUBJECT CLASSIFICATION}

Inhaler formulation and characters

\section{INTRODUCTION}

Today drugs were delivered through dry powder inhalers to treat respiratory diseases. The purpose of dry powder inhaler is to accumulate prescribed dose of powder aerosol into the air inhaled by patient in single large breath. During inhalation the powder particles were picked up and then broken up. Depending upon the size, particle will get deposited in different regions of respiratory tract during inhalation and releases drug to produce drug action. SS, AH, MS were very suitable for sustained release formulations [1-3]. Many research work were carried out with these drugs but orally inhalable sustained release formulation is new concept [4]. The drugs SS, AH, MS versus polymers PLGA (50:50), PLGA (75:25) and Eudragit RS100 in the ratio 1:1, which were kept constant to prepare microparticles for orally inhalable sustained release dry powder for effective treatment of respiratory diseases [5-7]. The emulsion solvent evaporation method is most influential for the production of microparticles [8-9].

\section{EXPERIMENTAL SETUP}

SS and AH was obtained as gift sample from Fourrts (India) Laboratories Ltd, Chennai. MS was obtained as gift sample from Orchid healthcare, Chennai. Poly (lactic-co-glycolic) acid (PLGA 75:25), Poly (lactic-co-glycolic) acid (PLGA 50:50) was obtained from Brimingham polymer Inc, USA. Eudragit RL100 and Eudragit RS 100 were obtained as gift from Evonik India Pvt. Ltd., Mumbai. Polyvinyl alcohol, HPMC, PVP K90 were obtained from Orchid Healthcare, Chennai. Lactohale LH100 was obtained as gift sample from DMV, Netherlands, Dichloromethane, methanol and acetonitrile was obtained from Qualigens, Mumbai and potassium dihydrogen orthophosphate, sodium chloride and sodium hydroxide were obtained from SD fine chemicals, Mumbai, India. MTT Reagent (Weigh $5 \mathrm{mg}$ of MTT in sterile condition and packed in 4ml amber bottle), Dulbecco's Modified Eagle's Medium (DMEM) media, Dimethyl sulphoxide (DMSO) $\mathrm{Co}_{2}$ Incubator, ELISA Plate used in Orange Progene Pvt Ltd., Chennai.

\subsection{Drug encapsulation:}

The microparticles were prepared by emulsion solvent evaporation method with some modifications. This method involves preparation of o/w emulsion between organic phase (OP) consisting of SS, AH and MS and polymers in methanol and aqueous phase (AP) containing 2\% w/v PVA [10-15]. Drugs and polymers were dissolve in methanol by sonication, using vibracel sonicator. For drug encapsulation, the organic phase was emulsified in aqueous phase by homogenization at 10000rpm for 10 minutes using a probe homogenizer. The emulsion obtained was stirred overnight (15 h) at $25 \pm 2{ }^{\circ} \mathrm{C}$ using magnetic stirrer to ensure complete evaporation of methanol. The encapsulated drug particles were recovered by centrifugation $\left(15,000 \mathrm{rpm}, 20 \mathrm{~min}, 4^{\circ} \mathrm{C}\right)$ using sorvall ultracentrifuge and the precipitate washed repeatedly three times with ice cold MilliQ water to ensure complete removal of polyvinyl alcohol. As a final point the product was dispersed in cold water and recovered by lyophilisation. Formulations T1-T9 were prepared keeping OP to AP ratio (1:5) and varying drug:polymer ratios given in Table 1. The unencapsulated drug presence were determined by measuring its absorbance at $278 \mathrm{~nm}(\mathrm{SS}), 257 \mathrm{~nm}(\mathrm{AH}), 351 \mathrm{~nm}(\mathrm{MS})$. 
Table 1. Formulation of microparticles

\begin{tabular}{|c|c|c|c|c|c|c|}
\hline $\begin{array}{c}\text { Trial } \\
\text { Code }\end{array}$ & Drug:Polymer (1:1) & $\begin{array}{c}\text { Weight } \\
\text { of } \\
\text { Drugs } \\
\text { (mg) }\end{array}$ & $\begin{array}{c}\text { Weight } \\
\text { of } \\
\text { polymer } \\
\text { (mg) }\end{array}$ & $\begin{array}{c}\text { Vol. of } \\
\text { DCM } \\
\text { (ml)- OP }\end{array}$ & $\begin{array}{c}\text { AP Vol. (2\% } \\
\text { PVA) (ml)- } \\
\text { AP }\end{array}$ & \% yield \\
\hline T1 & SS:PLGA(50:50) & 50 & 50 & 5 & 25 & $82.25 \pm 1.38$ \\
T2 & SS:PLGA(75:25) & 50 & 50 & 5 & 25 & $80.12 \pm 1.01$ \\
T3 & SS:Eudragit RS100 & 50 & 50 & 5 & 25 & $75.21 \pm 1.72$ \\
T4 & AH: PLGA(50:50) & 50 & 50 & 5 & 25 & $77.42 \pm 1.82$ \\
T5 & AH: PLGA(75:25) & 50 & 50 & 5 & 25 & $75.92 \pm 1.01$ \\
T6 & AH: Eudragit RS100 & 50 & 50 & 5 & 25 & $74.82 \pm 1.62$ \\
T7 & MS: PLGA(50:50) & 50 & 50 & 5 & 25 & $77.10 \pm 1.08$ \\
T8 & MS: PLGA(75:25) & 50 & 50 & 5 & 25 & $75.04 \pm 1.01$ \\
T9 & MS: Eudragit RS100 & 50 & 50 & 5 & 25 & $73.51 \pm 1.62$ \\
\hline
\end{tabular}

\subsection{Preparation of dry powder for oral inhalation:}

The prepared microparticles blended with inhalable grade lactose (lactohale) to enhance aerosol characters during inhalation [16-20]. This powder filled in to the size three hard empty gelatin capsules.

\subsection{Fourier Transform Infrared Spectroscopy (FTIR):}

Infrared spectrum produces fingerprint and characterization of the SS, AH and MS to indentify functional groups of the molecules. The band intensities are proportional to the concentration of the compounds. Infrared spectroscopy was used to determine various functional groups of the drug molecule.

\subsection{Scanning Electron Microscopy (SEM):}

The diameter, structural and surface morphology of prepared encapsulated particles were obtained through scanning electron microscope. The scanning electron microscopy (VEGA3) with maximum magnification $1000000 * X$ and a resolution $3 \mathrm{~nm}$ at a voltage of $30 \mathrm{kV}$ were used and investigated surface morphology and shape of the prepared microparticles. The specimens were examined with maximum vacuum and with accelerating voltage of 5-15 KV [21-24].

\subsection{Entrapment Efficiency:}

Drugs were extracted from the microparticles with $0.1 \mathrm{M}$ sodium hydroxide after dissolving it in acetonitrile. After suitable dilutions, the drug content was measured in a UV-Vis spectrophotometer (Jasco) at 278nm (SS), 257nm (AH), $351 \mathrm{~nm}(\mathrm{MS})$. Entrapment efficiency was calculated using the following formula:

Entrapment efficiency was calculated using the following formula:

Entrapment efficiency $=$ Estimated \% drug content $\times 100$

$\%$ drug content (theoretical)

Percentage Yield:

The percentage yield was calculated by using the following formula.

Percentage yield $=\underline{\text { Actual wt. of microspheres }} \times 100$

Wt. of starting materials

\subsection{Particle size evaluation by laser diffraction:}

The particle sizes of microparicles were estimated by laser diffraction method. The Helos particle size determination with Sympatec GMbh systems were used for estimation of particle size. The dry powder 100mg was used to achieve the required obscuration of $5 \%$. The particle size data obtained were represented as $\mathrm{D}_{0.5}$.

\subsection{In vitro deposition studies:}

The anderson cascade impactor dealings particle size in accord with pharmacopoeia specifications [25-26]. The eight stages of Andersen Cascade Impactor $(\mathrm{ACl})$ used for measuring the aerodynamic particle size distribution generated by dry powder inhaler such as rotahaler. The samples were collected on the surface of the collection plates, the middle was the preseparator connect with the glass expansion chamber and the right were the sieves, which filter the particles 


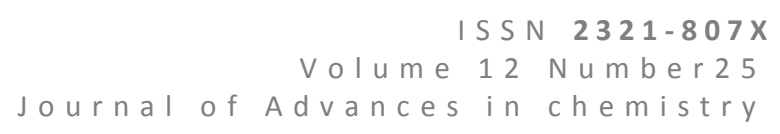

according to their size [27-31]. The collection plates were layered with silicone oil to prevents bouncing of the particles while performing the studies. The outlet of the $\mathrm{ACl}$ is connected to a critical flow controller to create flow during testing. The airflow was $60 \mathrm{~L} / \mathrm{min}$. The $\mathrm{ACl}$ operation conditions were specified in Table 2.

Table 2. Operating conditions and theoretical cut-off diameters of $\mathrm{ACl}$

\begin{tabular}{|c|c|}
\hline ACI Parameters & ACI Results \\
\hline Flow rate (L/min) & 60 \\
Time per actuation (s) & 4 \\
Volume per actuation (L) & 4 \\
Cut off diameter $(\mu \mathrm{m})$ & \\
Stage 0 & 5.7 \\
Stage 1 & 4.5 \\
Stage 2 & 3.4 \\
Stage 3 & 2.3 \\
Stage 4 & 1.4 \\
Stage 5 & 0.8 \\
Stage 6 & 0.40 \\
Stage 7 & 0.12 \\
Stage 8 & Filter \\
\hline
\end{tabular}

\subsection{In vitro drug release:}

The dialysis bag dispersion technique used to calculate in vitro release of SS, AH and MS from the microparticles [32-36]. The diffusion medium phosphate buffer saline (PBS) pH 7.4 and a dialysis membrane of $14 \mathrm{kDa}$ molecular weight (Himedia, Mumbai, India) were used. An aqueous dispersion of $10 \mathrm{mg}$ of drugs kept in a dialysis bag and sealed at both ends. The dialysis bag was immersed in $250 \mathrm{ml}$ of diffusion medium (sodium phosphate buffer, $\mathrm{pH} 7.4$ at $37^{\circ} \mathrm{C}$ ) and stirred at $100 \mathrm{rpm}$. Samples were withdrawn at predetermined time intervals, and the receptor phase was replenished with same volume of phosphate buffer saline after each sample was withdrawn. Samples were filtered through $0.46 \mu \mathrm{m}$ filter and appropriately diluted with $\mathrm{pH} 7.4$ phosphate buffer saline. Absorbance of the samples was determined by UV/Vis spectrophotometry with $\mathrm{pH} 7.4$ phosphate buffer saline as blank. The cumulative percent drug at various time intervals was determined and plotted against time. All experiments were done in triplicate.

\subsection{Filter paper disc diffusion method:}

The disc diffusion method was used to evaluate antibacterial and antifungal activity. The test samples were prepared with the solvent dimethyl formamide. The $6 \mathrm{~mm}$ diameter sterile paper disc impregnated with extracted test samples of microparticles deposited on the surface of agar medium. The standard used was the ciprofloxacin $(100 \mathrm{mcg} / \mathrm{ml})$ to study actimicrobial activity of microparticles prepared. The filter paper disc diffusion method was used to test by employing 24 hours cultures of the respective microorganisms. The sterile nutrient agar used as medium and test organisms were seeded by homogenously mixing $1 \mathrm{ml}$ of inoculums with $20 \mathrm{ml}$ sterile melted nutrient agar colled at $50^{\circ} \mathrm{C}$ in a sterile petridish to get solidified. All the test samples and standard were impregnated in whatman filter paper disc and kept above the medium in the petridish and petridish kept undisturbed for 2 hours at room temperature. The petridish were incubated for 24 hours at $37^{\circ} \mathrm{C}$ and inhibition zone $(\mathrm{mm})$ was measured. Antibacterial efficiency at different concentration $(250 \mathrm{mcg} / \mathrm{ml}$, $500 \mathrm{mcg} / \mathrm{ml}, 1 \mathrm{mg} / \mathrm{ml}$ ) were determined by using the filter paper disc diffusion method. The null bacterial growth of minimum dimension of the zone around the filter paper disc was measured and calculated the zone of inhibition.

\subsection{Method of MTT assay process}

The alveolar epithelial cancer cell line A549 was used in the cell viability assay. The MTT reagent (3-(4, 5-dimethylthiazolyl-2)-2, 5-diphenyltetrazolium bromide) used to know cell viability. 500-10,000 cells were plated in a 96 well plate by Leaving the 8 th wells empty for controls. The seeded cells where incubated $\left(37{ }^{\circ} \mathrm{C}, 5 \% \mathrm{CO}_{2}\right)$ overnight to allow the cells to attach to the wells. $2 \mu \mathrm{l}$ (depends on the concentration) of drug of interest dissolved in DMSO to each well. Placed on a shaking table, $150 \mathrm{rpm}$ for $5 \mathrm{~min}$, to thoroughly mix the samples into the media. Incubated $\left(37^{\circ} \mathrm{C}, 5 \% \mathrm{CO}_{2}\right)$ for $1-5$ days to allow the drug/toxin to take effect. $20 \mu \mathrm{l} \mathrm{MTT}(5 \mathrm{mg} / \mathrm{ml}$ in DMSO) solution added to each well and placed on a shaking table, $150 \mathrm{rpm}$ for $5 \mathrm{~min}$, to thoroughly mix the MTT into the media. Plates are incubated $\left(37^{\circ} \mathrm{C}, 5 \% \mathrm{CO}_{2}\right)$ for $1-5$ $\mathrm{h}$ to allow the MTT to be metabolized. Dump off the media and Resuspend formazan (MTT metabolic product) in $150 \mu \mathrm{l}$ DMSO with shaking table, $150 \mathrm{rpm}$ for $5 \mathrm{~min}$, to thoroughly mix the formazan into the solvent. The process detail presented in Table 3. Read optical density at $560 \mathrm{~nm}$ and subtract background at $660 \mathrm{~nm}$. 
Table 3. MTT assay process

\begin{tabular}{|c|c|c|c|c|c|c|c|c|c|c|c|}
\hline \multirow{2}{*}{$\begin{array}{l}\text { S. } \\
\text { No }\end{array}$} & \multirow[t]{2}{*}{ Reagents } & \multicolumn{9}{|c|}{ Test Sample (T1-T9) } & \multirow{2}{*}{$\begin{array}{l}\text { Blank (B) } \\
\text { B }\end{array}$} \\
\hline & & T1 & T2 & T3 & T4 & T5 & T6 & T7 & T8 & T9 & \\
\hline \multirow[t]{2}{*}{1} & Cell culture & $\begin{array}{l}100 \\
\mu l\end{array}$ & $\begin{array}{l}100 \\
\mu l\end{array}$ & $\begin{array}{l}100 \\
\mu l\end{array}$ & $\begin{array}{l}100 \\
\mu l\end{array}$ & $\begin{array}{l}100 \\
\mu l\end{array}$ & $\begin{array}{l}100 \\
\mu l\end{array}$ & $\begin{array}{l}100 \\
\mu l\end{array}$ & $100 \mu \mathrm{l}$ & $\begin{array}{l}100 \\
\mu l\end{array}$ & - \\
\hline & \multicolumn{11}{|c|}{ Incubate at $37^{\circ} \mathrm{C}$ for Over night } \\
\hline 2 & $\begin{array}{l}\text { MTT } \\
\text { Reagent }\end{array}$ & $10 \mu \mathrm{l}$ & $10 \mu \mathrm{l}$ & $10 \mu \mathrm{l}$ & $10 \mu \mathrm{l}$ & $10 \mu \mathrm{l}$ & $10 \mu \mathrm{l}$ & $10 \mu \mathrm{l}$ & $10 \mu \mathrm{l}$ & $\begin{array}{l}10 \\
\mu l\end{array}$ & $10 \mu \mathrm{l}$ \\
\hline \multirow[t]{2}{*}{3} & PBS & - & - & - & - & - & - & - & - & - & $100 \mu \mathrm{l}$ \\
\hline & \multicolumn{11}{|c|}{ Incubate at $37^{\circ} \mathrm{C}$ for $2-4 \mathrm{hrs}$} \\
\hline 4 & DMSO & $150 \mu$ & $150 \mu$ & $150 \mu$ & $\begin{array}{l}150 \\
\mu l\end{array}$ & $150 \mu$ & $150 \mu$ & $150 \mu$ & $150 \mu \mathrm{l}$ & $150 \mu$ & $150 \mu \mathrm{l}$ \\
\hline & & & & & 37 & $\mathrm{or}$ & $s$ & & & & \\
\hline
\end{tabular}

\section{RESULT AND DISCUSSION}

In the present study, microparticles were prepared by modified solvent evaporation method. The drugs were encapsuled with polymers in aqueous:organic phase. Encapsulation process involves vibracell sonication, homogenization, centrifugation and then freeze drying to yield microparticles [37-41]. Kept organic aqueous solution ratio as $1: 5$ (30 ml of organic:aqueous solution as $5: 25 \mathrm{ml}$ respectively mixed with 1:1 drug polymer ratio). Presence of polymer ensures good yield of microparticles [42-43].

\section{Particle size analysis, entrapment efficiency of microparticles, weight variation and drug content of DPI:}

The particle size, and entrapment efficiency were evaluated for microparticles and demonstrated in Table 4. The size distribution of microparticles (laser diffraction) was observed for formulations T1-T9. The mean particle size of microparticles of formulation T1, was better than other formulation T2-T9. Entrapment efficiency for formulations with PLGA (50:50) were better than PLGA (75:25) and Eudragit RS100. The Table 5 described on the weight variation and drug content of capsule contains homogenous mixture of Drug:lactohale (1:19) of formulations T1-T9. The average weight of filled capsules was $20 \mathrm{mg}$ containing $1 \mathrm{mg}$ of drugs (SS, AH and MS). In all formulation measurement, the uniformity of weight and drug content in the capsule was achieved.

Table 4. Particle size, entrapment efficiency of microparticles

\begin{tabular}{|c|c|c|}
\hline Trial Code & $\begin{array}{c}\text { Particle size }\left(\mathbf{D}_{0.5} \mathbf{n m}\right) \\
\text { Mean } \pm \text { SD }\end{array}$ & $\begin{array}{c}\text { Entrapment } \\
\text { efficiency }\end{array}$ \\
\hline T1 & $1.94 \pm 0.6$ & $76.62 \pm 0.32$ \\
T2 & $1.92 \pm 0.2$ & $73.12 \pm 0.41$ \\
T3 & $1.82 \pm 0.8$ & $71.16 \pm 0.54$ \\
T4 & $1.93 \pm 0.5$ & $75.14 \pm 0.21$ \\
T5 & $1.91 \pm 0.3$ & $74.24 \pm 0.12$ \\
T6 & $1.88 \pm 0.6$ & $72.17 \pm 0.15$ \\
T7 & $1.91 \pm 0.1$ & $72.12 \pm 0.36$ \\
T8 & $1.90 \pm 0.5$ & $70.06 \pm 0.47$ \\
T9 & $1.86 \pm 0.7$ & $69.09 \pm 0.26$ \\
\hline
\end{tabular}

Table 5. Weight variation and drug content of dry powder inhaler

\begin{tabular}{|c|c|c|}
\hline Trial Code & $\begin{array}{c}\text { Weight Variation } \\
(\mathrm{mg} \pm \mathrm{SD})\end{array}$ & $\begin{array}{c}\text { Drug Content } \\
(\%)\end{array}$ \\
& & \\
\hline
\end{tabular}




\begin{tabular}{|c|c|c|}
\hline T1 & $20.06 \pm 0.05$ & $99.2-100.5$ \\
T2 & $20.11 \pm 0.12$ & $99.0-101.4$ \\
T3 & $19.94 \pm 0.20$ & $98.9-102.5$ \\
T4 & $20.09 \pm 0.08$ & $99.1-100.8$ \\
T5 & $20.21 \pm 0.22$ & $99.0-100.2$ \\
T6 & $19.93 \pm 0.23$ & $98.5-102.0$ \\
T7 & $20.09 \pm 0.08$ & $98.1-100.2$ \\
T8 & $20.01 \pm 0.10$ & $99.7-101.2$ \\
T9 & $19.93 \pm 0.20$ & $98.4-100.9$ \\
\hline
\end{tabular}

\section{Drugs compatibility in formulations by FTIR spectra:}

The interaction of drugs in formulations T1-T9 were evaluated in Fourier transform infrared spectroscopy (FTIR-Perkin Elmer of scanning range $450-4000 \mathrm{~cm}^{-1}$ ) was presented in Fig. 1-12. Spectral graphs were given as wave number $\left(\mathrm{cm}^{-1}\right)$ against Transmittance (\%). SS produces sharp bands at wavelength of about $1000 \mathrm{~cm}^{-1}$, as spectra of formulation also show bands at same wavelength, but somewhat less intense. AH shows peaks at 3350, 3400, 1590, 1540 and $700 \mathrm{~cm}^{-1}$ [44-45]. The peak of $\mathrm{AH}$ at 3400,3345 and $1074 \mathrm{~cm}^{-1}$ becomes relatively narrow, which could be attributed to the stretching vibration of phenolic hydroxyls (OH bond), and confirms the interactions of phenolic hydroxyl groups [46]. MS exhibits many aromatic $\mathrm{CH}$ peaks observed from $2900 \mathrm{~cm}^{-1}$ to $3000 \mathrm{~cm}^{-1}$. There is no difference in the positions of absorption bands was observed in the spectra of drugs (SS, AH and MS) and formulation trials T1-T9, demonstrating no chemical interaction between drugs and polymer in solid state. From the observation drugs were found to be stable in formulation trials T1-T9.

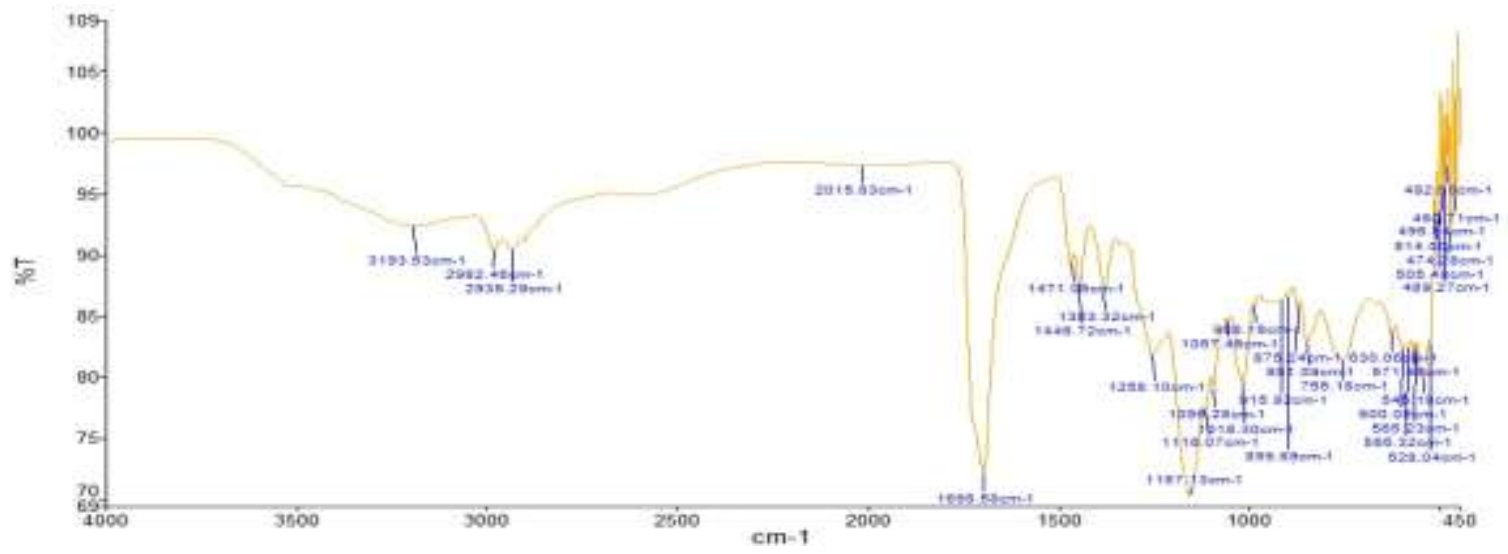

Fig. 1. FTIR graph of salbutamol sulphate

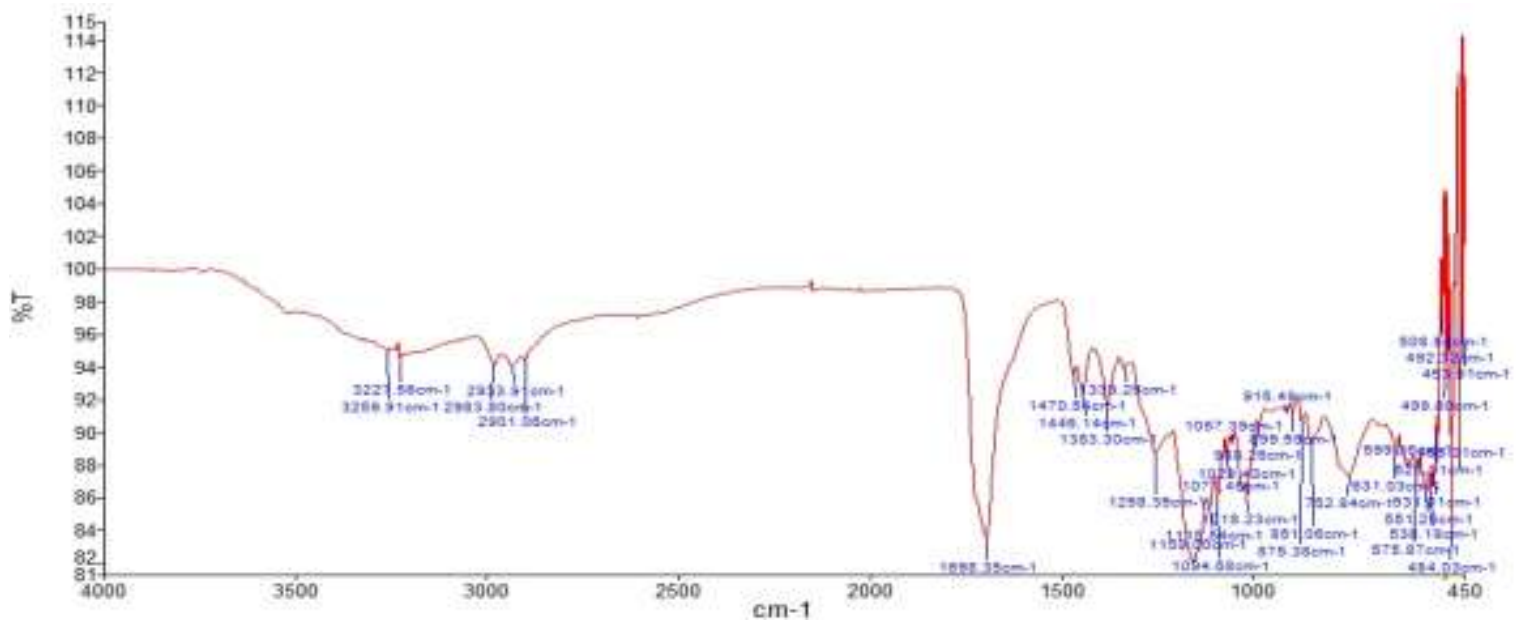

Fig. 2. FTIR graph of formulation trial T1 
IS SN $2321-807 X$

Volume $12 \mathrm{Number} 25$

Journal of Advances in chemistry

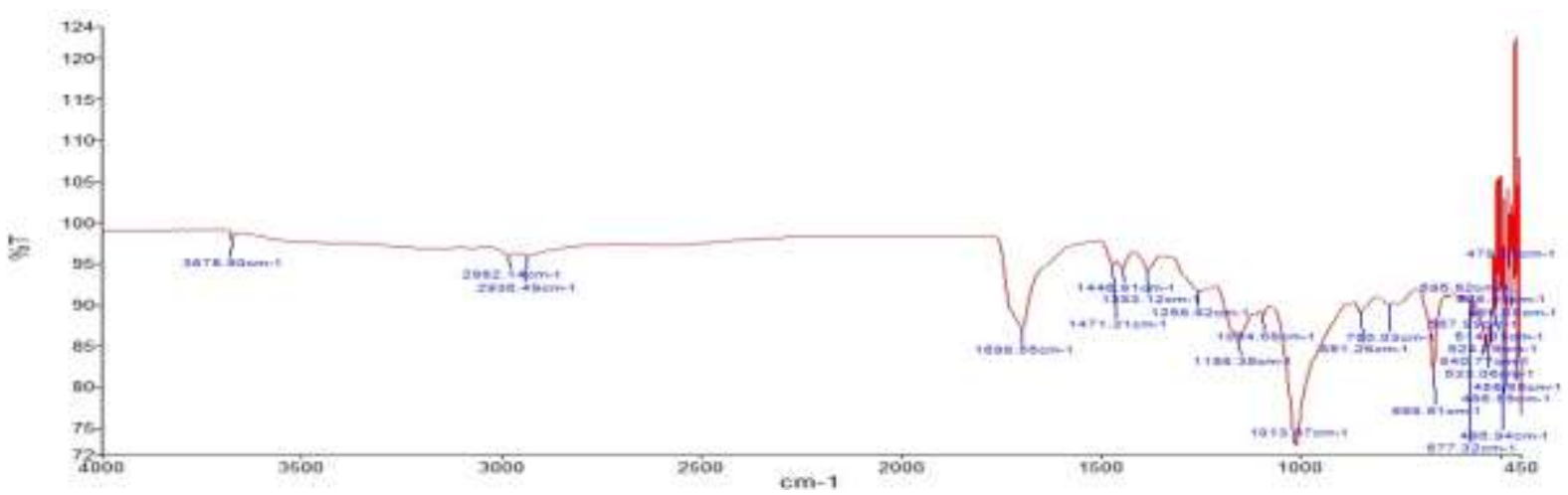

Fig. 3. FTIR graph of formulation trial T2

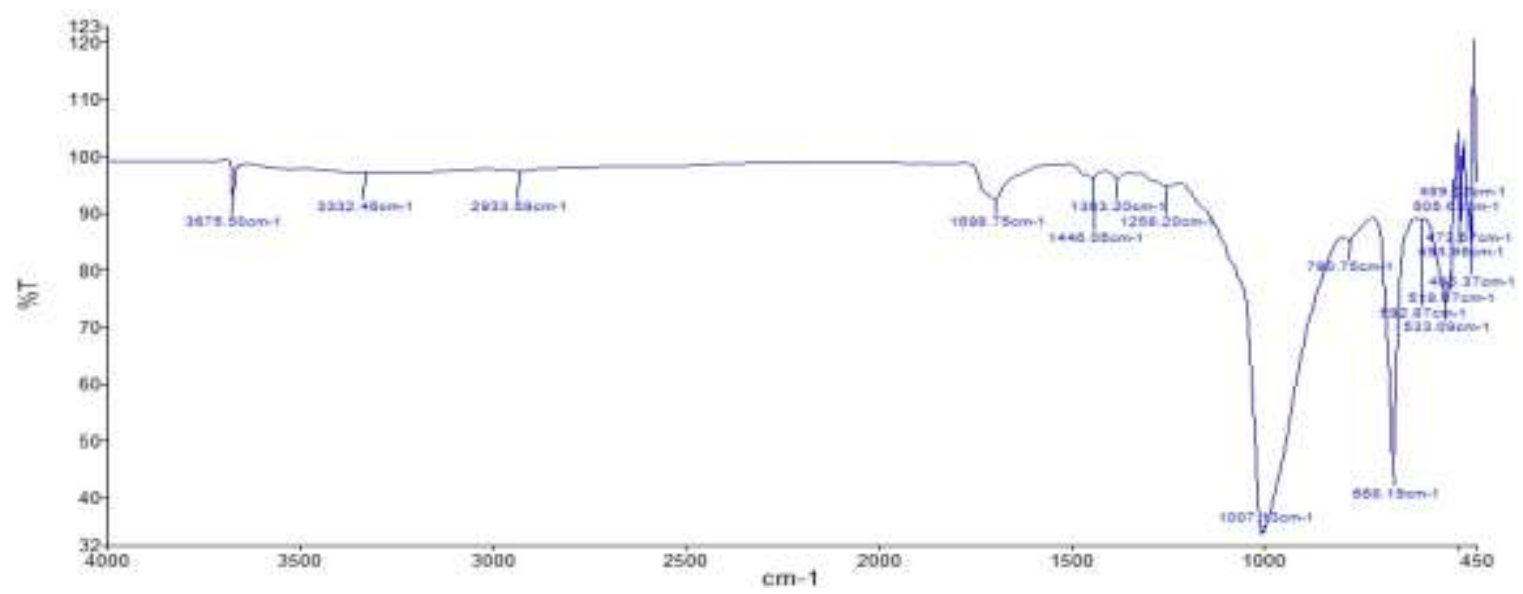

Fig. 4. FTIR graph of formulation trial T3

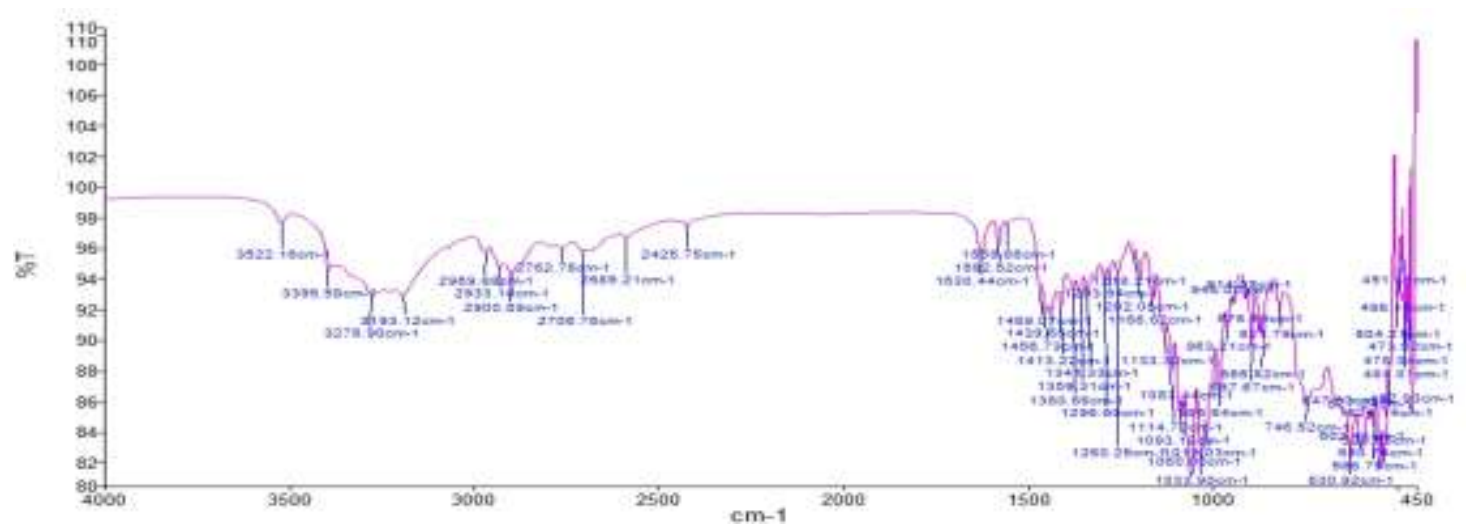

Fig. 5. FTIR graph of ambroxol hydrochloride

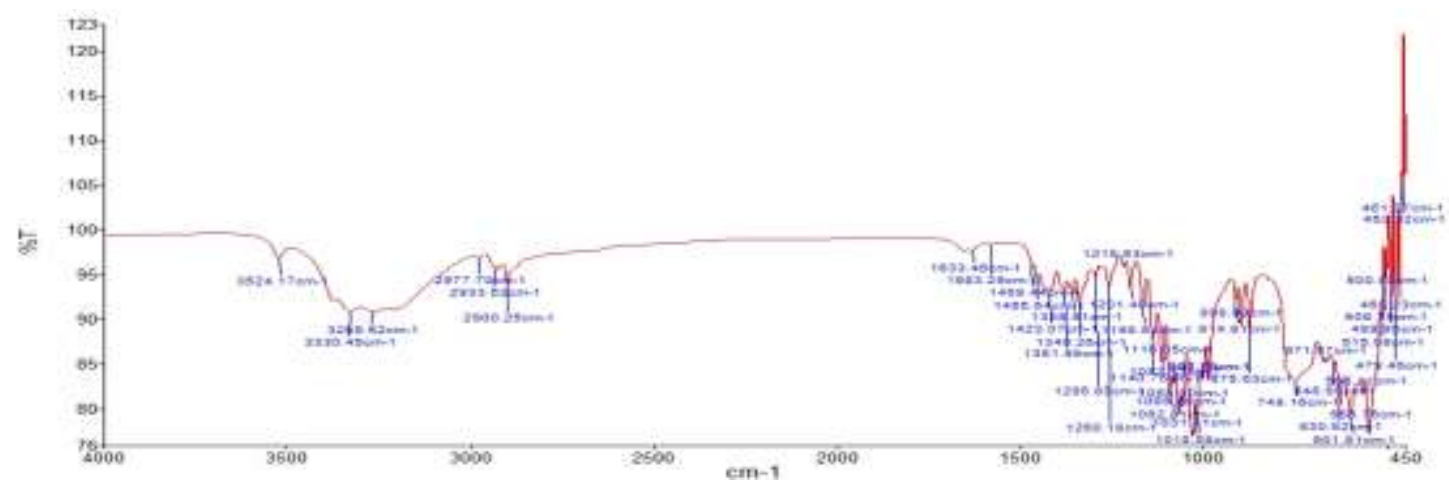

Fig. 6. FTIR graph of formulation trial T4

$\mathbf{5 6 8 4} \mid \mathrm{P}$ a g e

$\mathrm{Dec}$ em be 2016

ww w . cir world. co m 


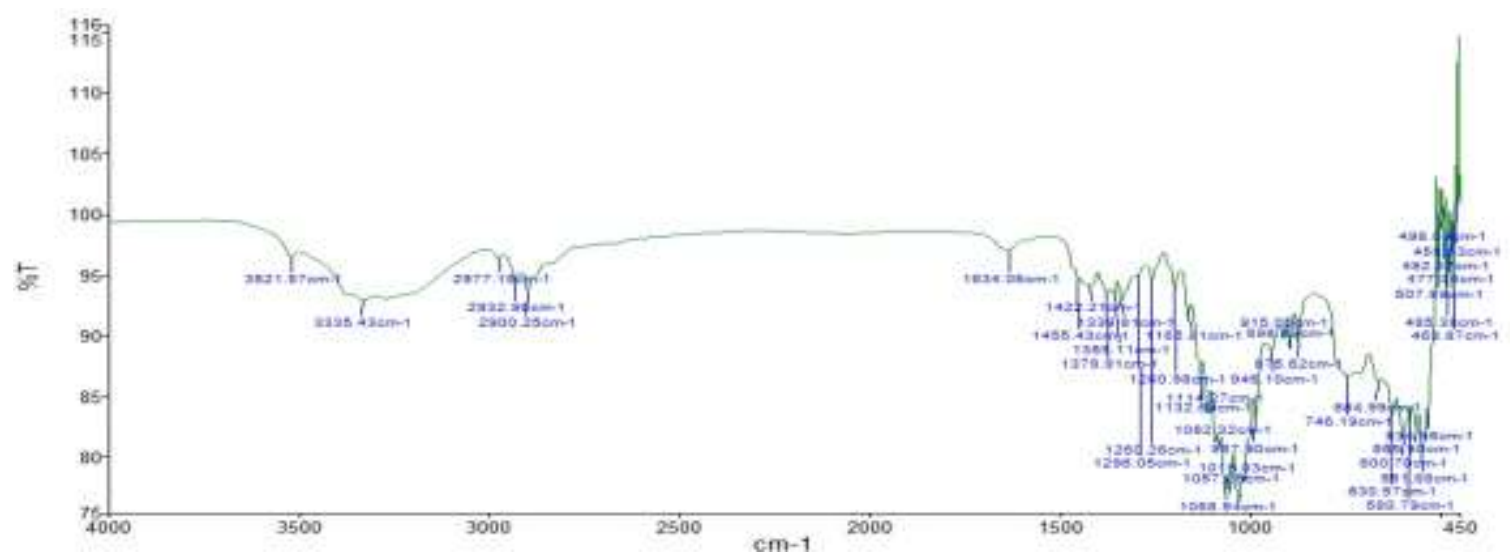

Fig. 7. FTIR graph of formulation trial T5

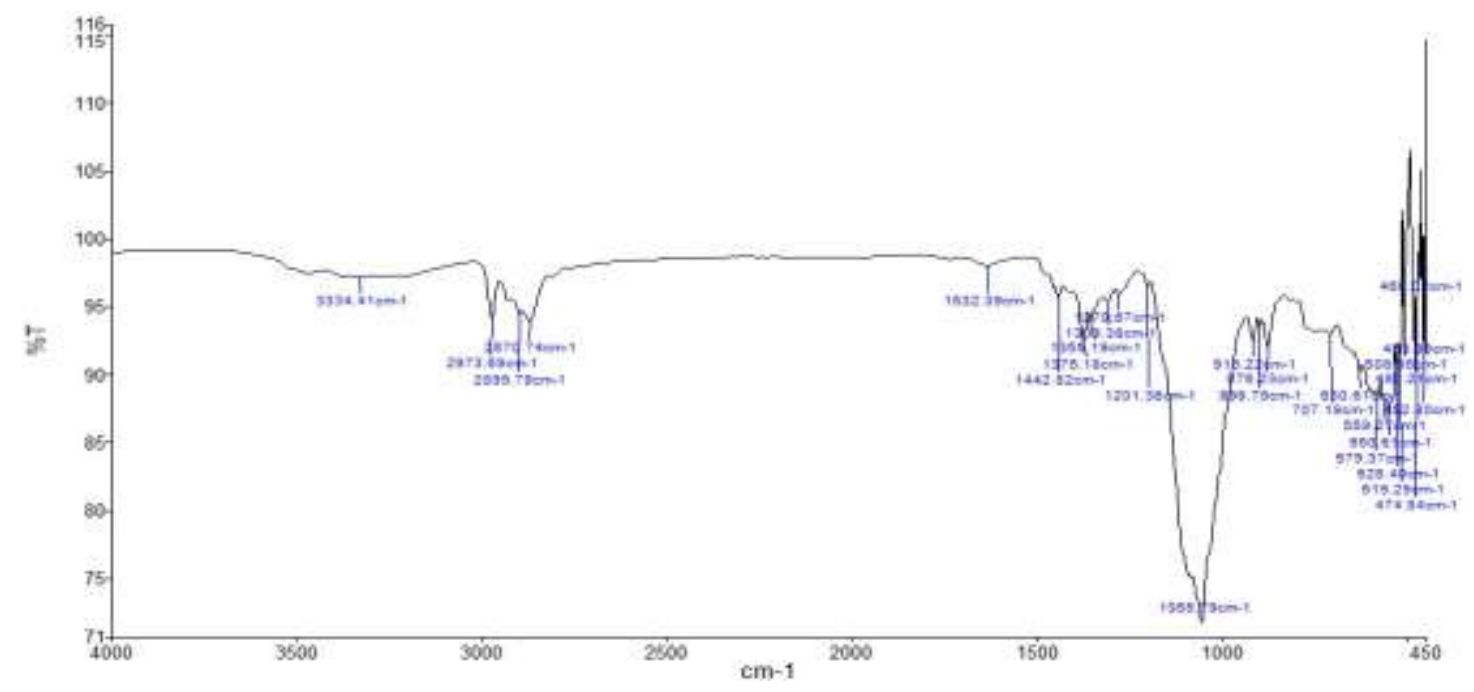

Fig. 8. FTIR graph of formulation trial T6

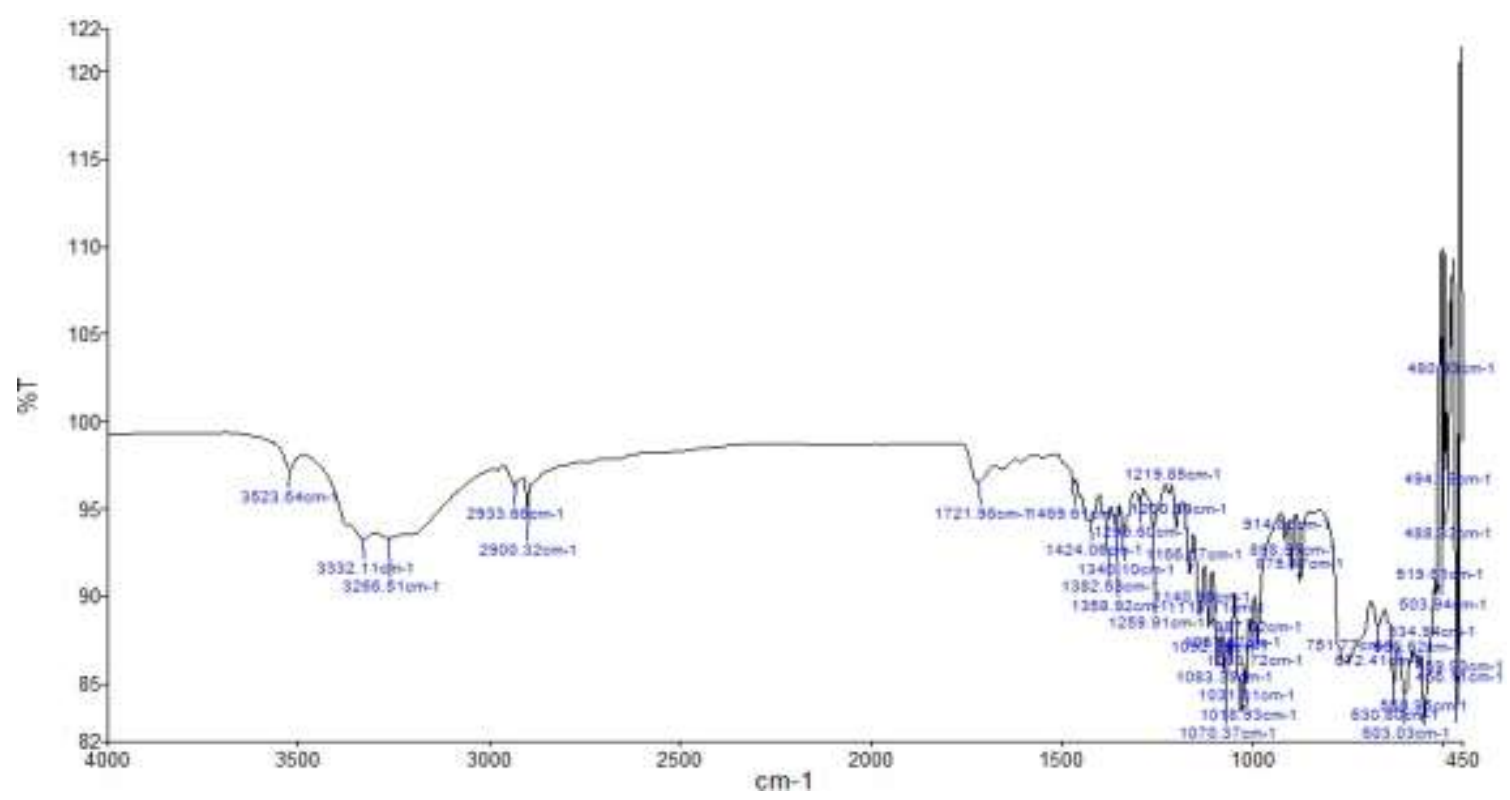

Fig. 9. FTIR graph of montelukast sodium 


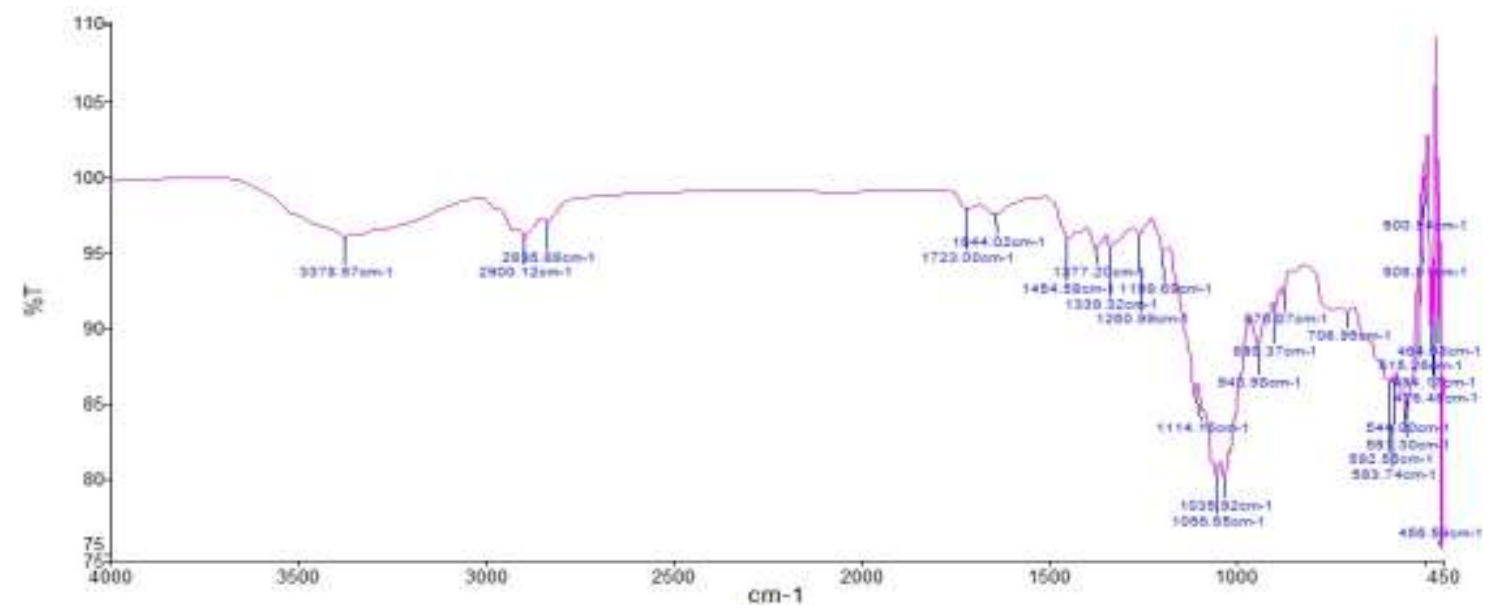

Fig. 10. FTIR graph of formulation trial T7

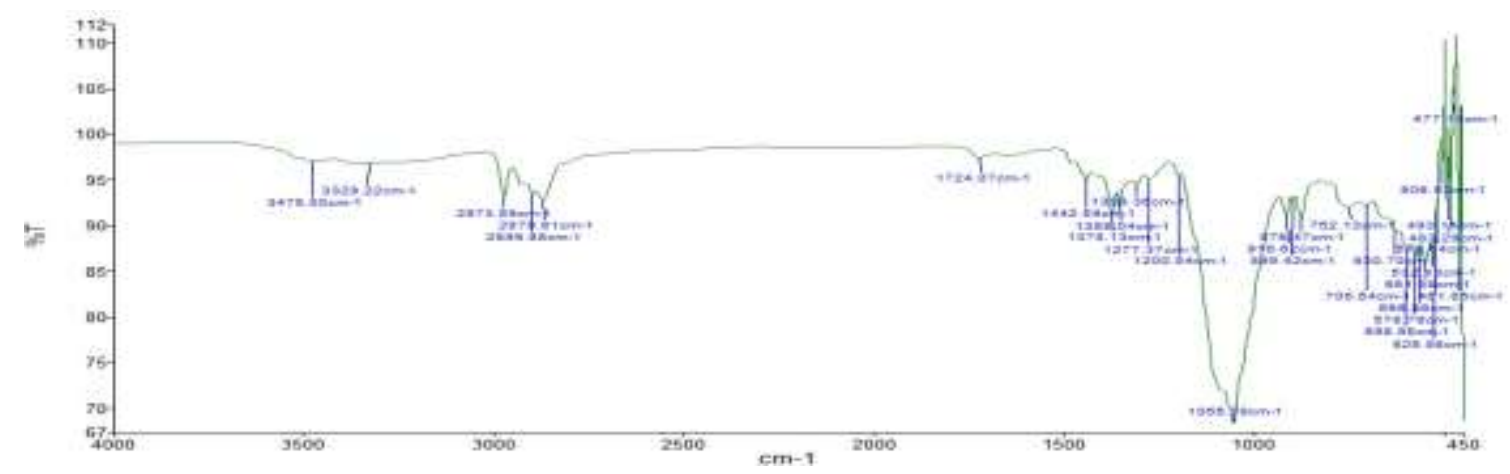

Fig. 11. FTIR graph of formulation trial T8

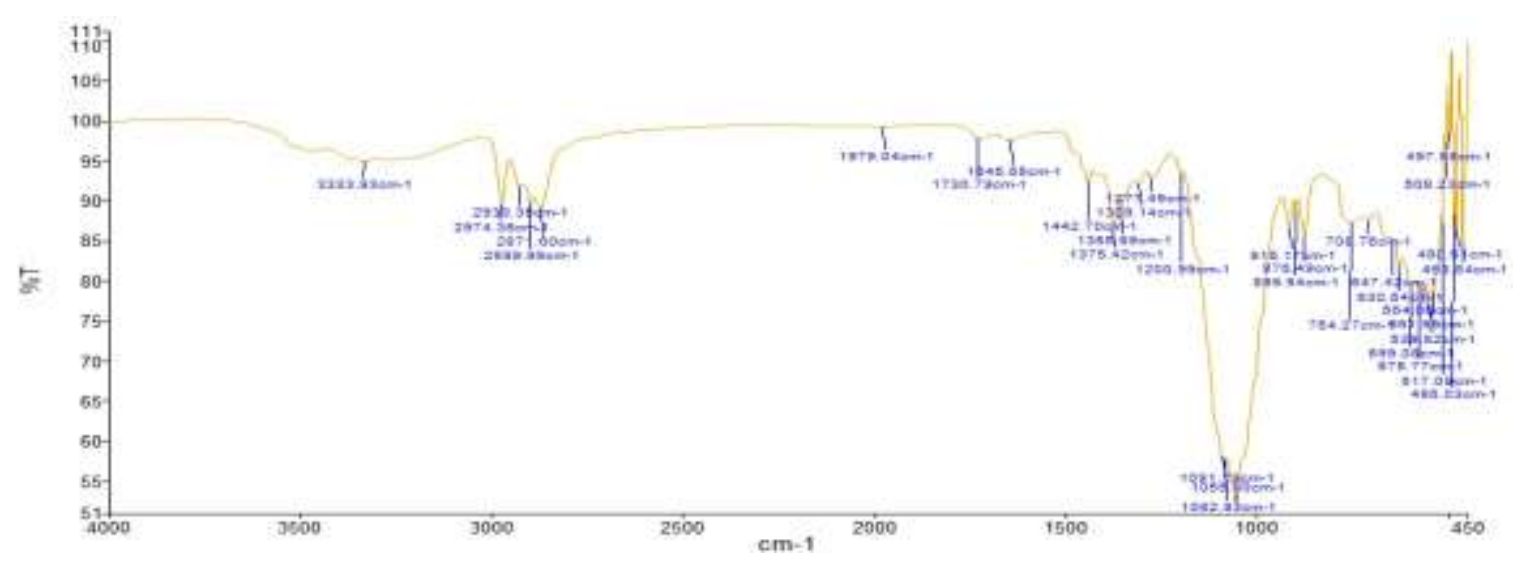

Fig. 12. FTIR graph of formulation trial T9

\section{Scanning electron microscopy:}

Scanning electron microscope (SEM-VEGA3) analysis showed the surface morphology of microparticles Fig. 13-21. The scanning range was $400-4000 \mathrm{~cm}^{-1}$ and the resolution was $2 / \mathrm{cm}$. The SEM image showed microparticles are nearly spherical in nature. 


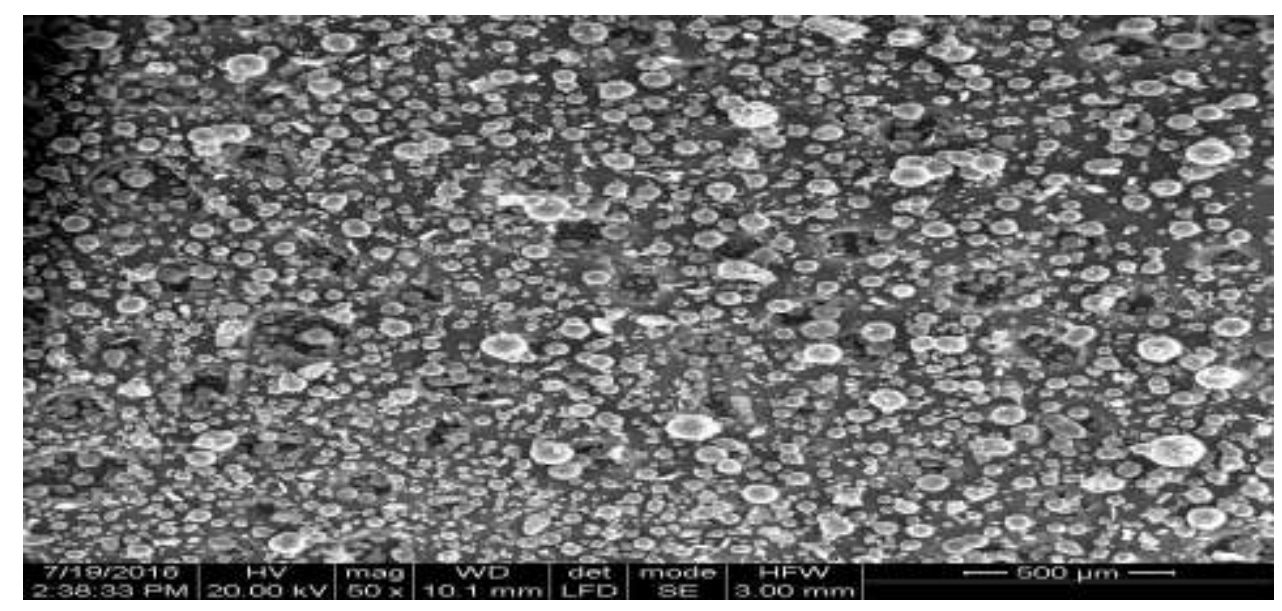

Fig. 13. SEM photograph of formulation T1

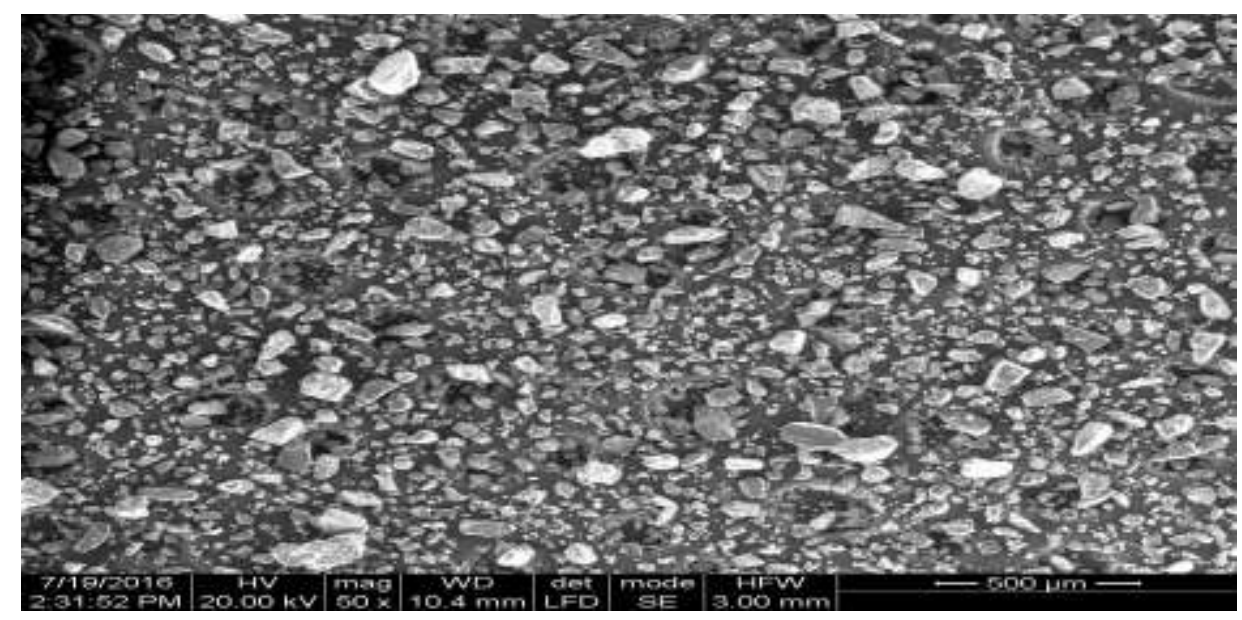

Fig. 14. SEM photograph of formulation T2

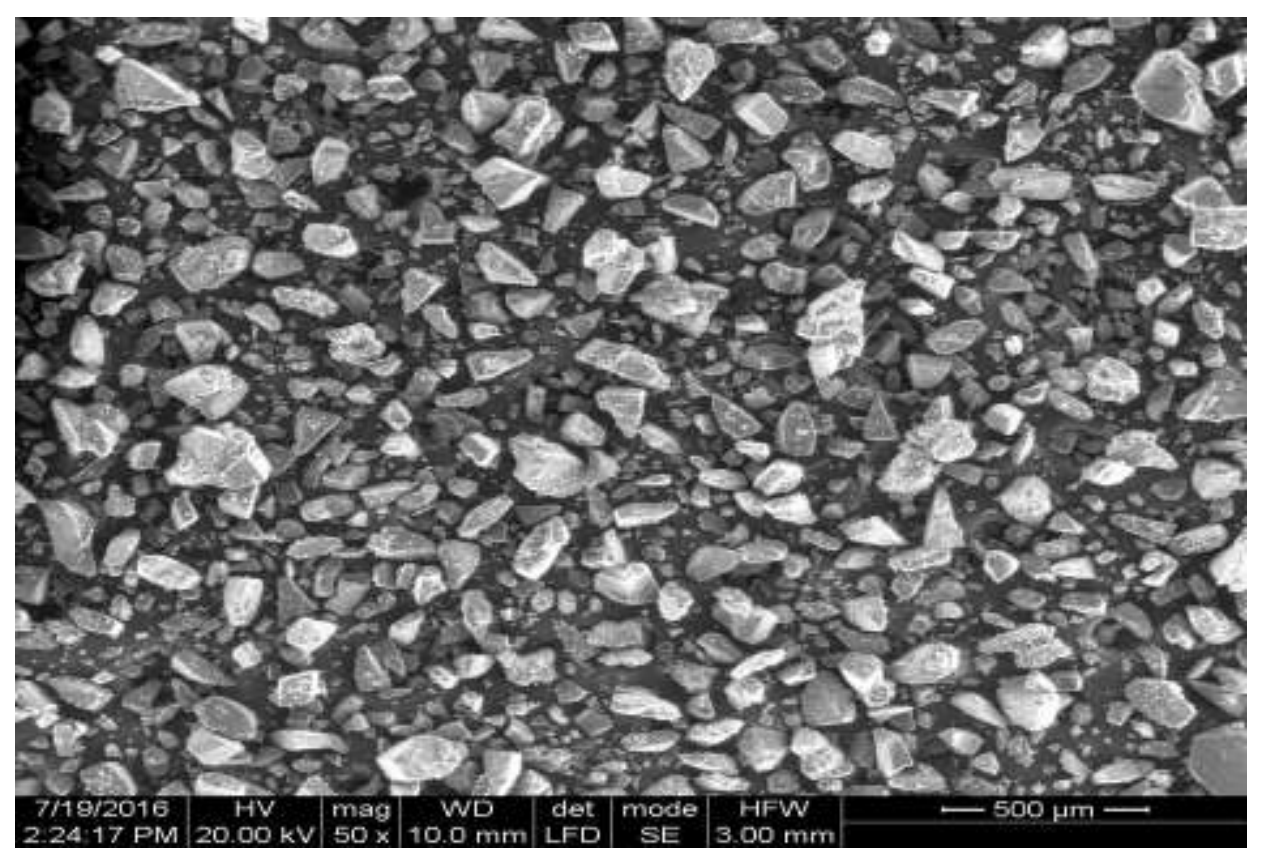

Fig. 15. SEM photograph of formulation T3 


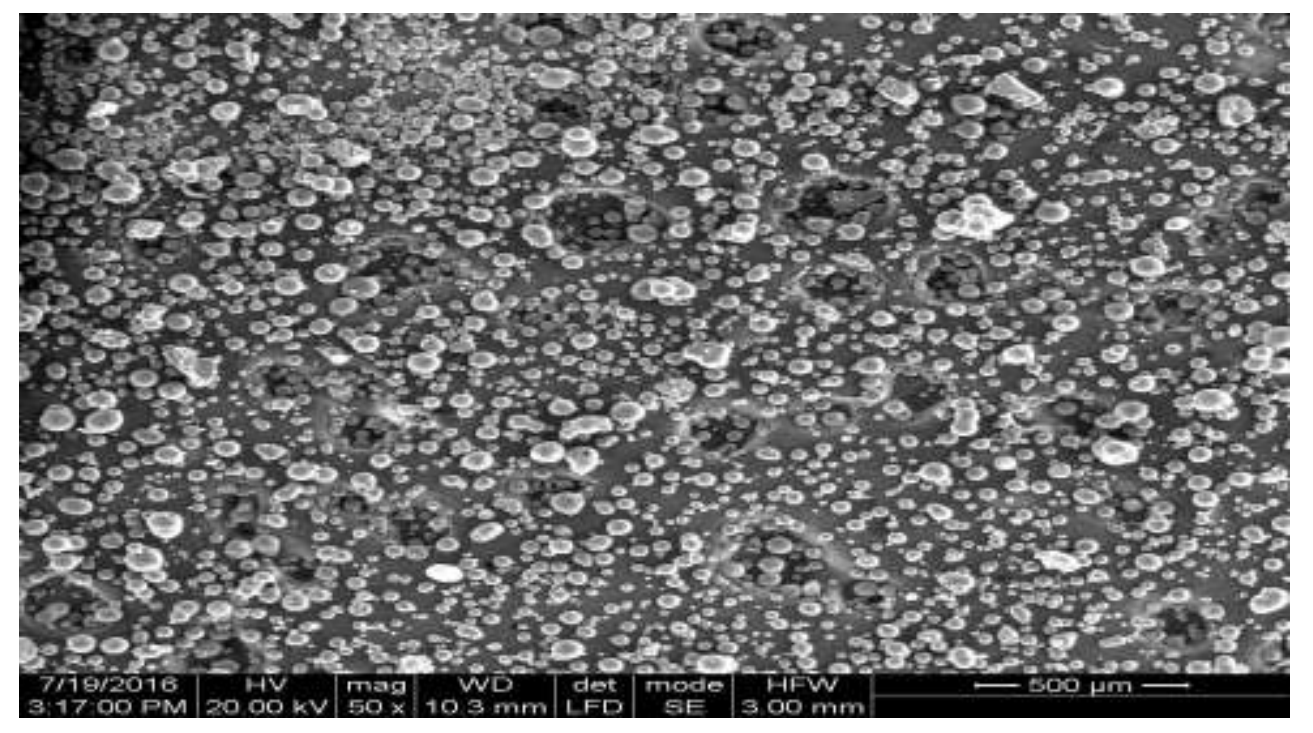

Fig. 16. SEM photograph of formulation T4

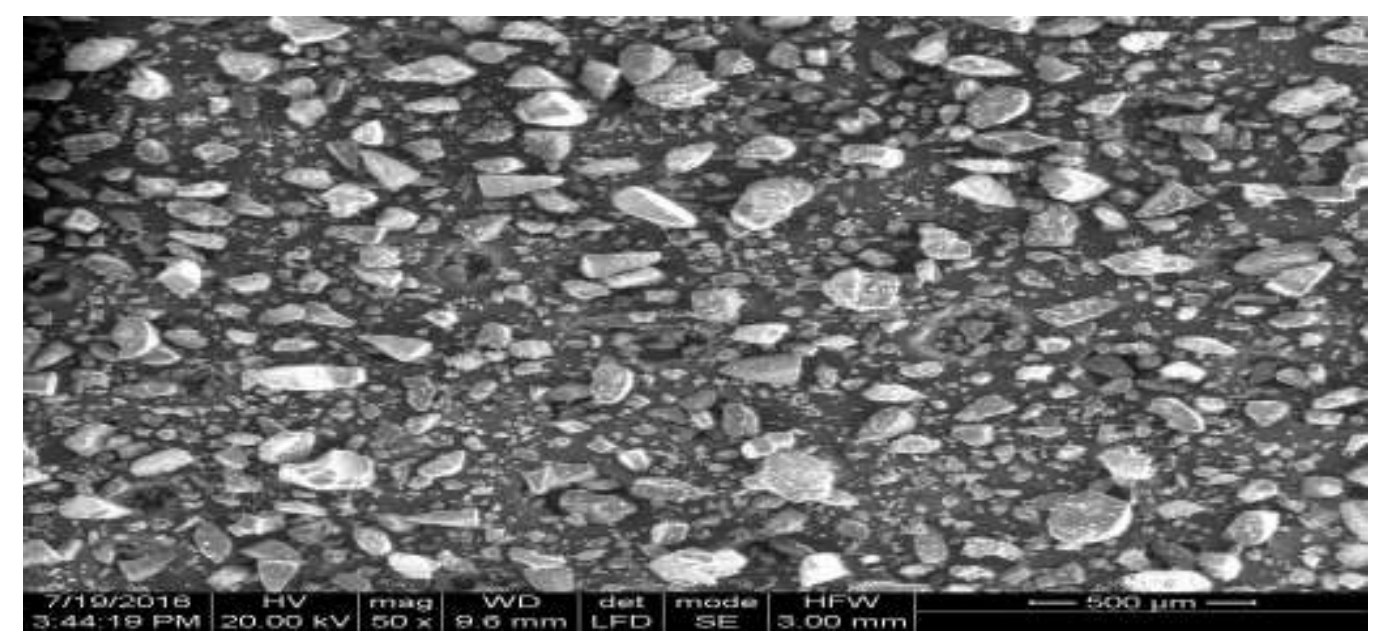

Fig. 17. SEM photograph of formulation T5

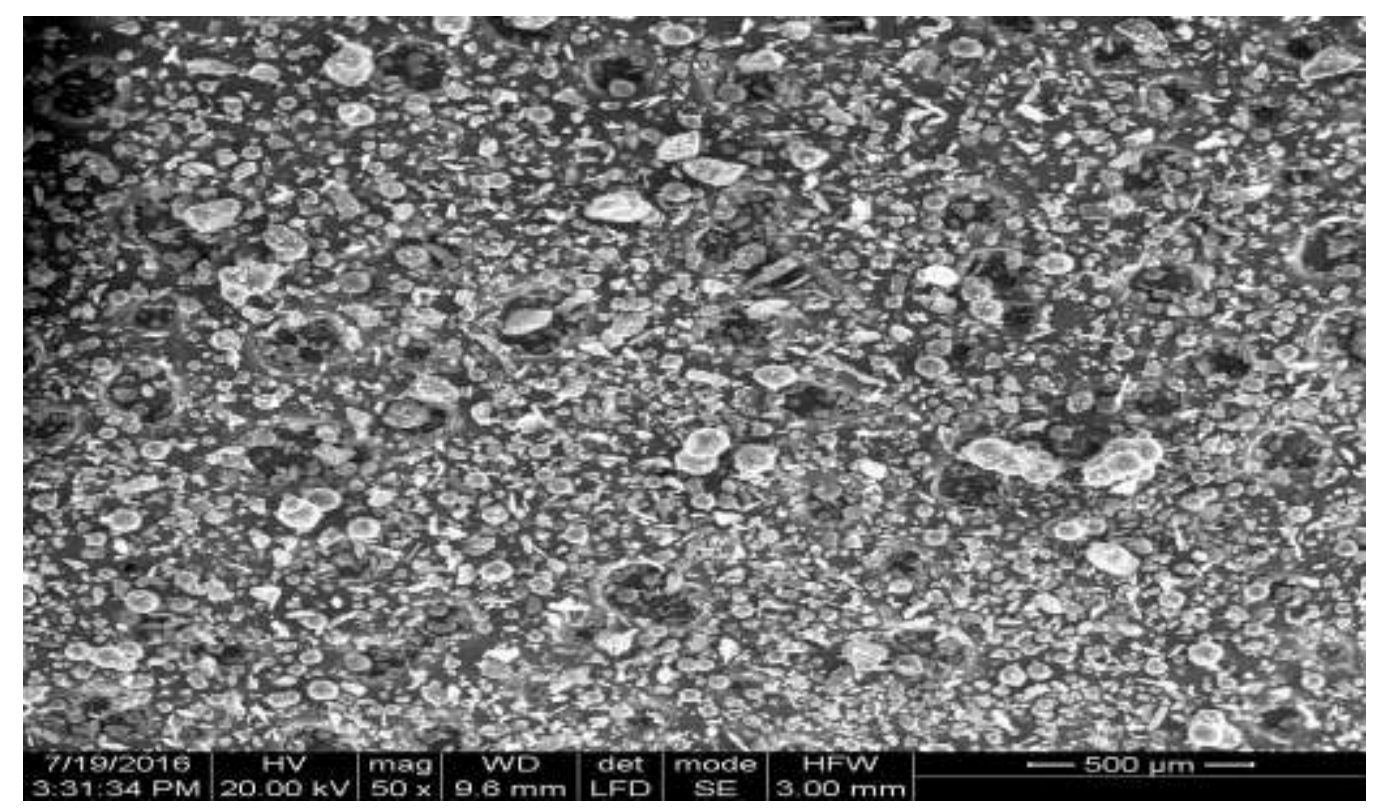

Fig. 18. SEM photograph of formulation T6 


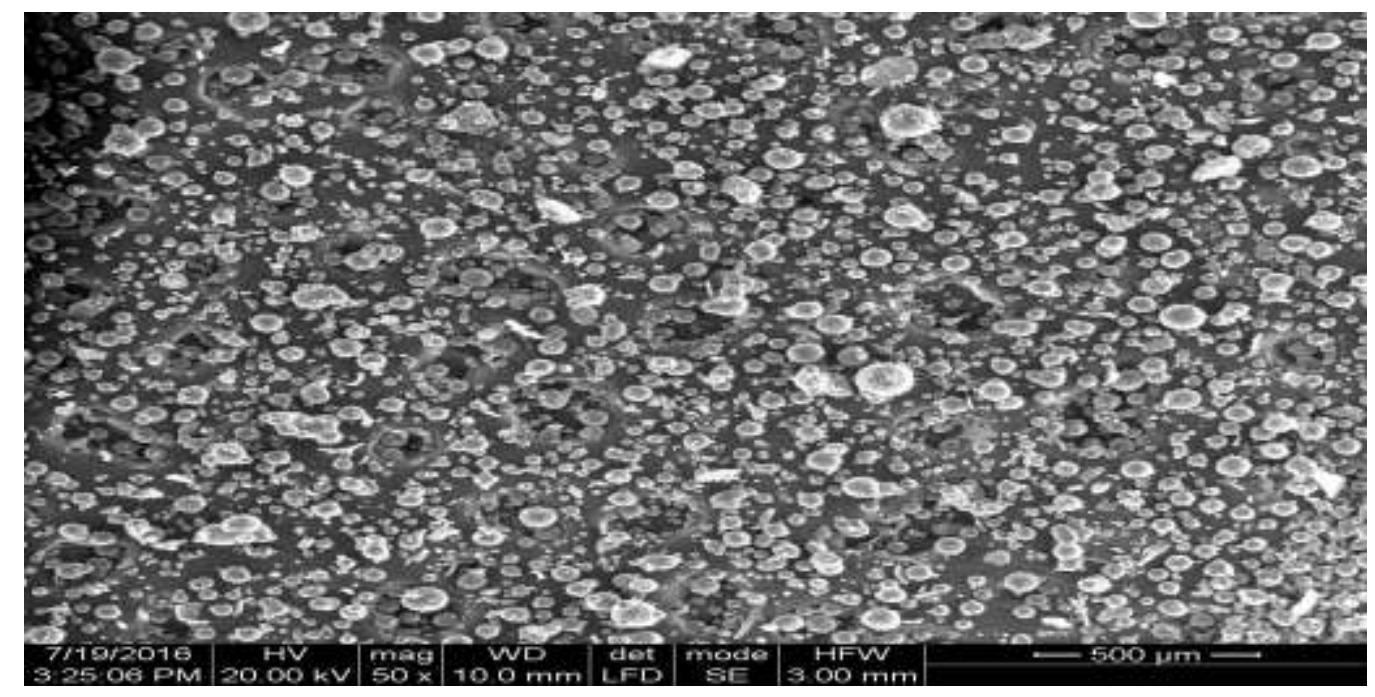

Fig. 19. SEM photograph of formulation T7

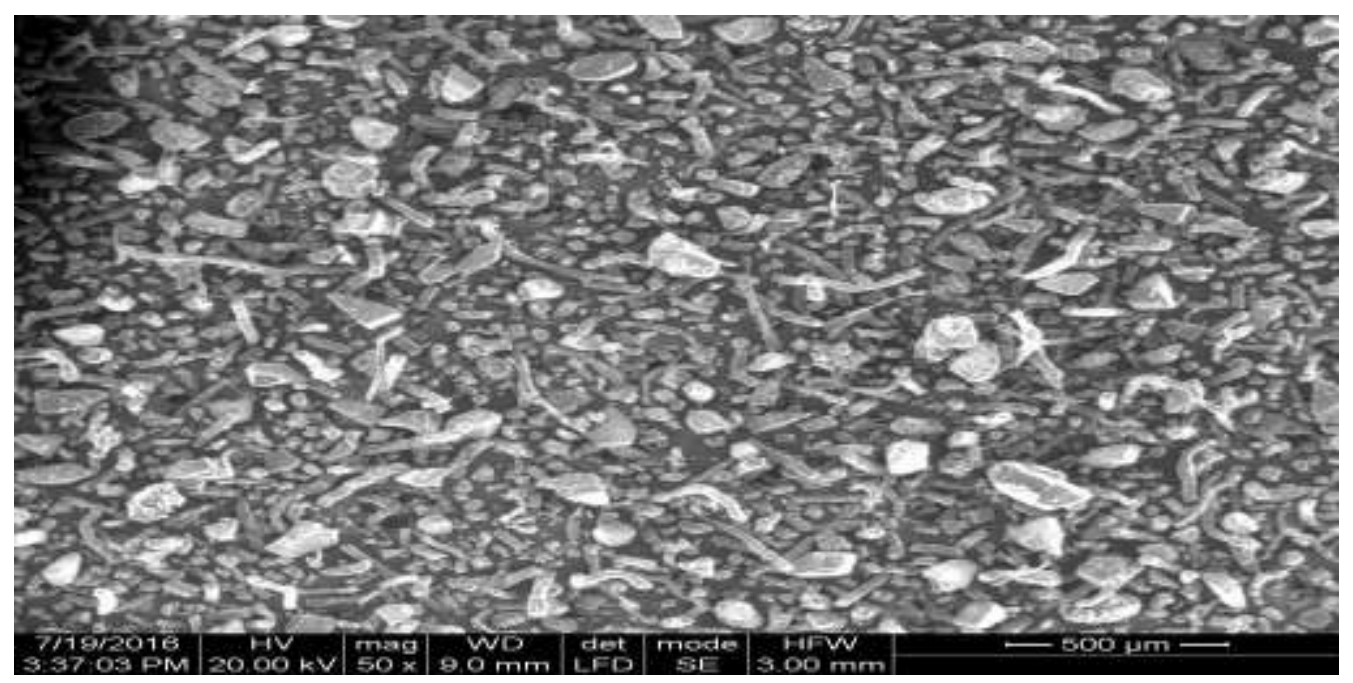

Fig. 20. SEM photograph of formulation T8

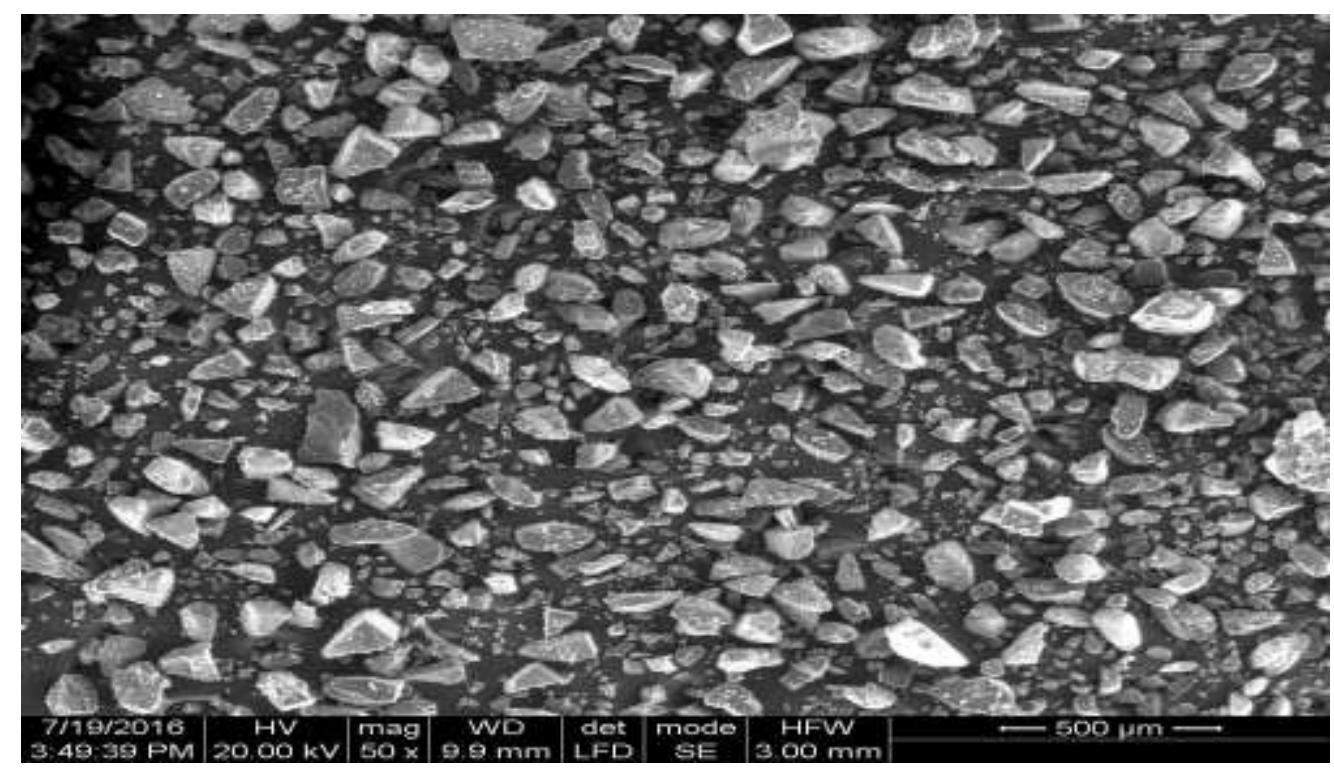

Fig. 21. SEM photograph of formulation T9 


\section{Anderson cascade impaction studies:}

The In vitro depositions of powder particles in the lung were evaluated by powder particle distribution in the stages of Anderson cascade impactor (ACl, Copley Scientific)[47]. The distribution of powder particles were graphically demonstrated in Fig. 22-30, showing mean (SD) percent emitted dose deposited on each stage of the ACI using Rotahaler at $60 \mathrm{~L} \mathrm{~min}^{-1}(\mathrm{n}=6)$. The respiratory fraction[48-49] (particle deposition in stage 2-8) and mass median aerodynamic diameter of formulation T1-T3 were given in Table 6, T4-T6 were given in Table 7 and T7-T9 were given in Table 8.

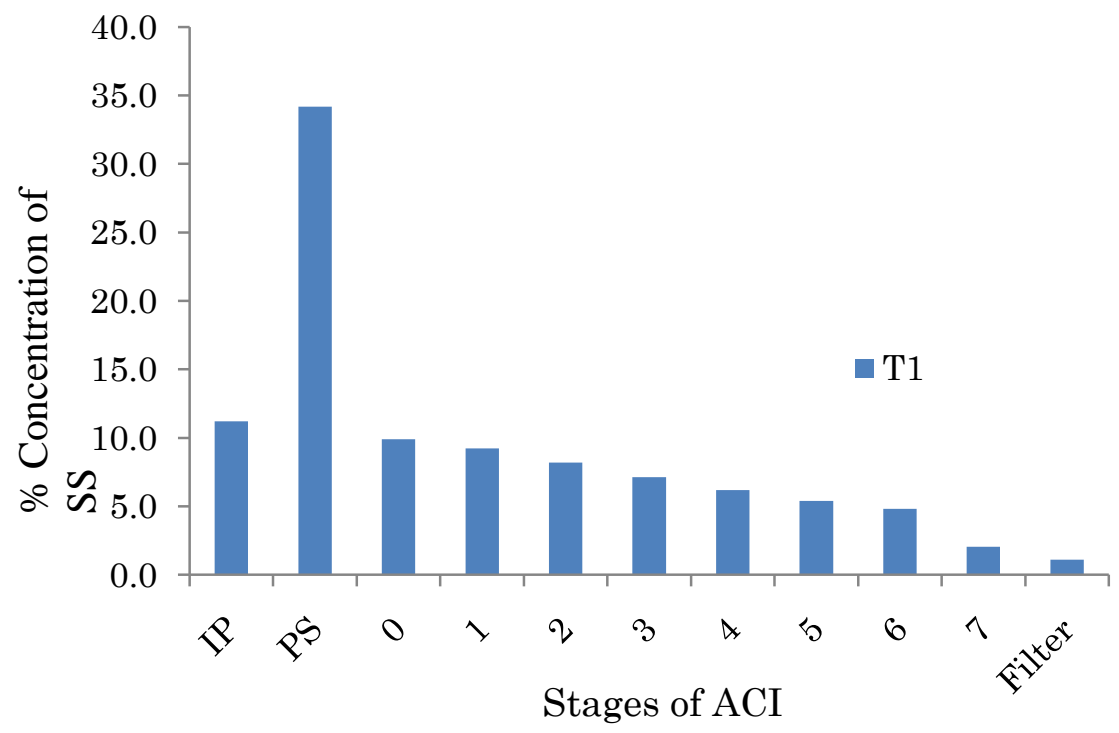

Fig. 22. ACI for \% deposition profiles in each stage for formulation T1

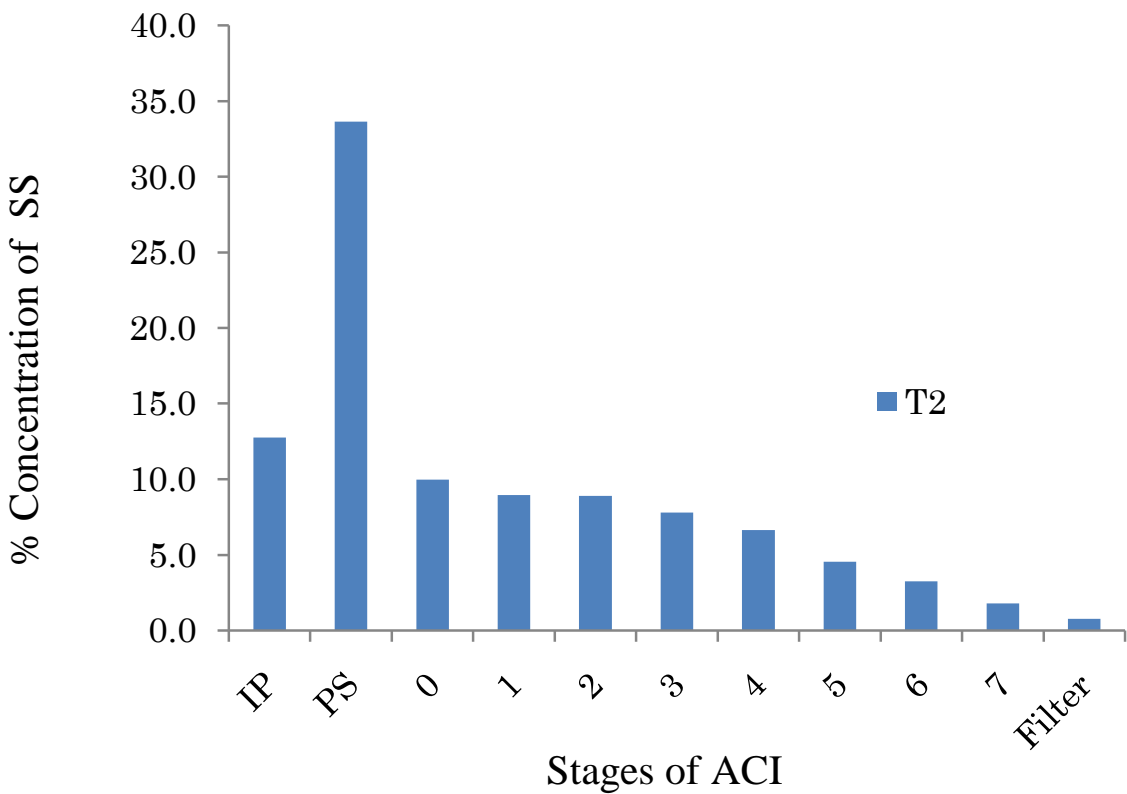

Fig. 23. ACl for \% deposition profiles in each stage for formulation T2 


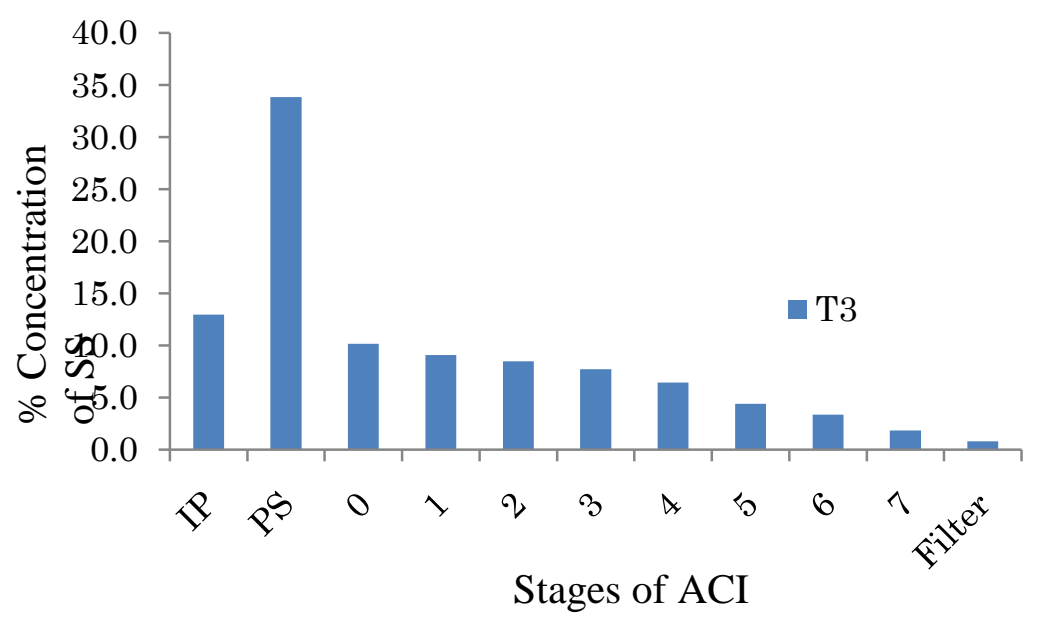

Fig. 24. ACI for \% deposition profiles in each stage for formulation T3

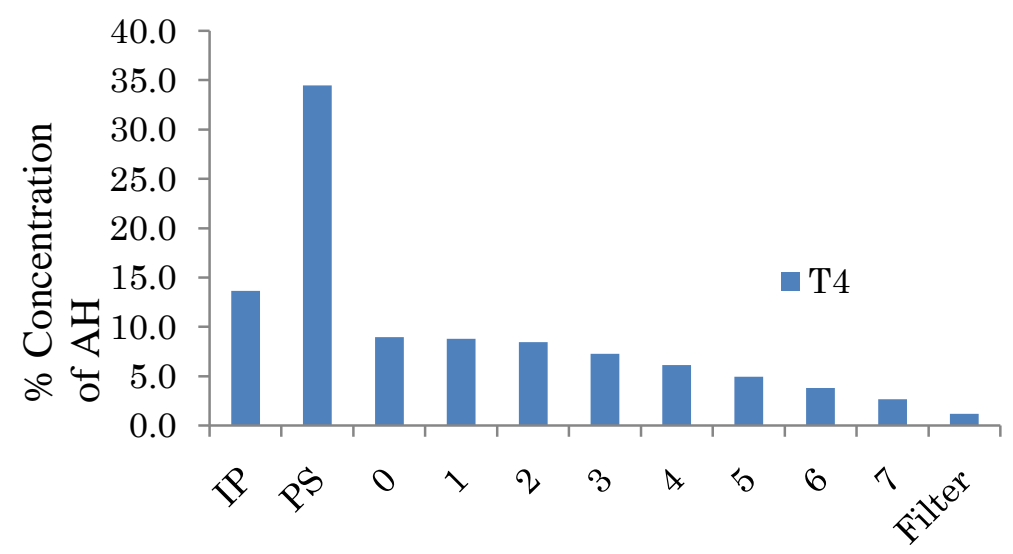

Stages of ACI

Fig. 25. ACl for \% deposition profiles in each stage for formulation T4

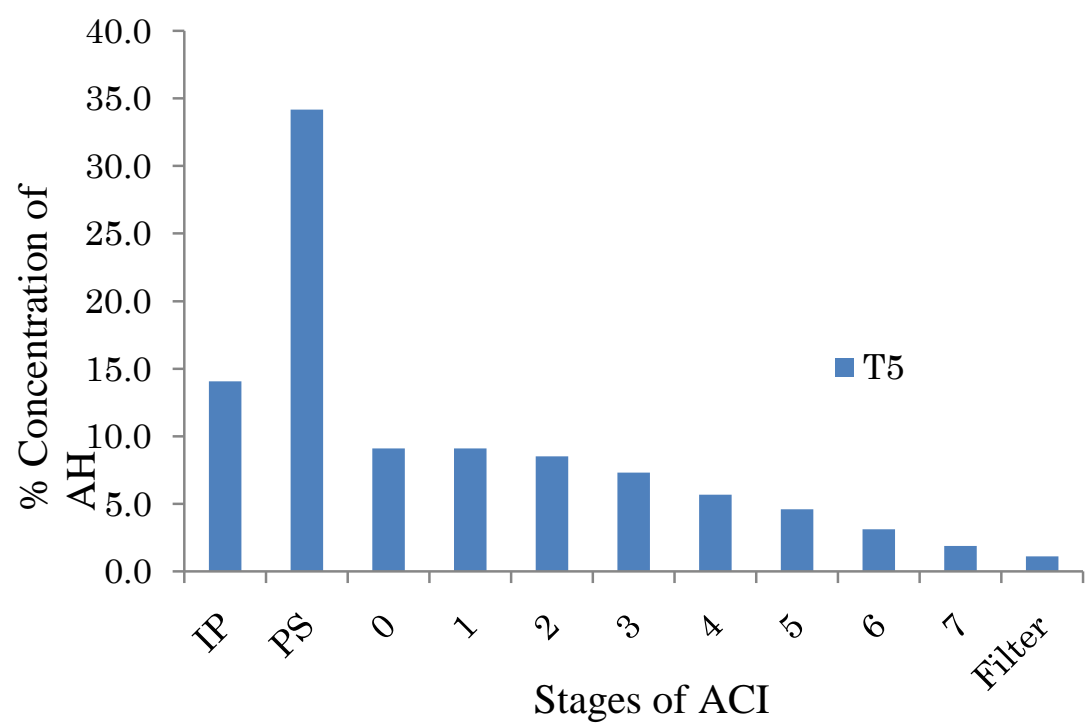

Fig. 26. ACl for \% deposition profiles in each stage for formulation T5 


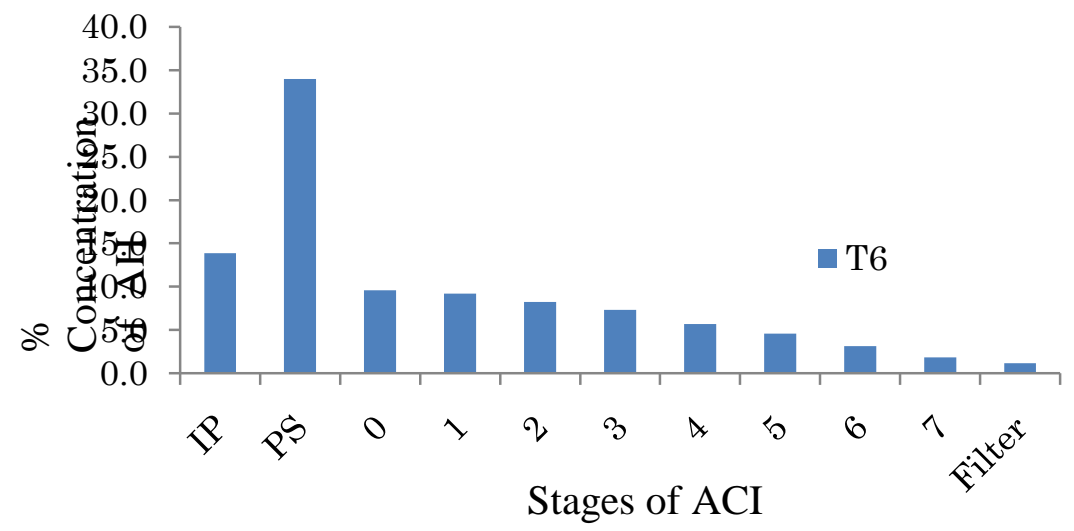

Fig. 27. ACI for \% deposition profiles in each stage for formulation T6

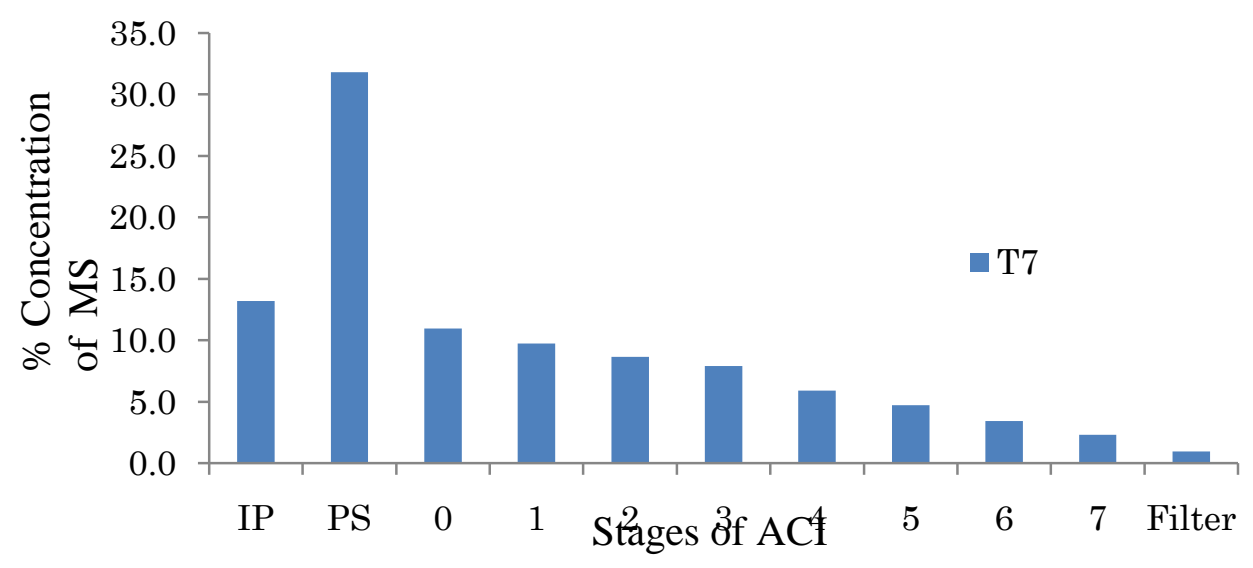

Fig. 28. ACI for \% deposition profiles in each stage for formulation T7

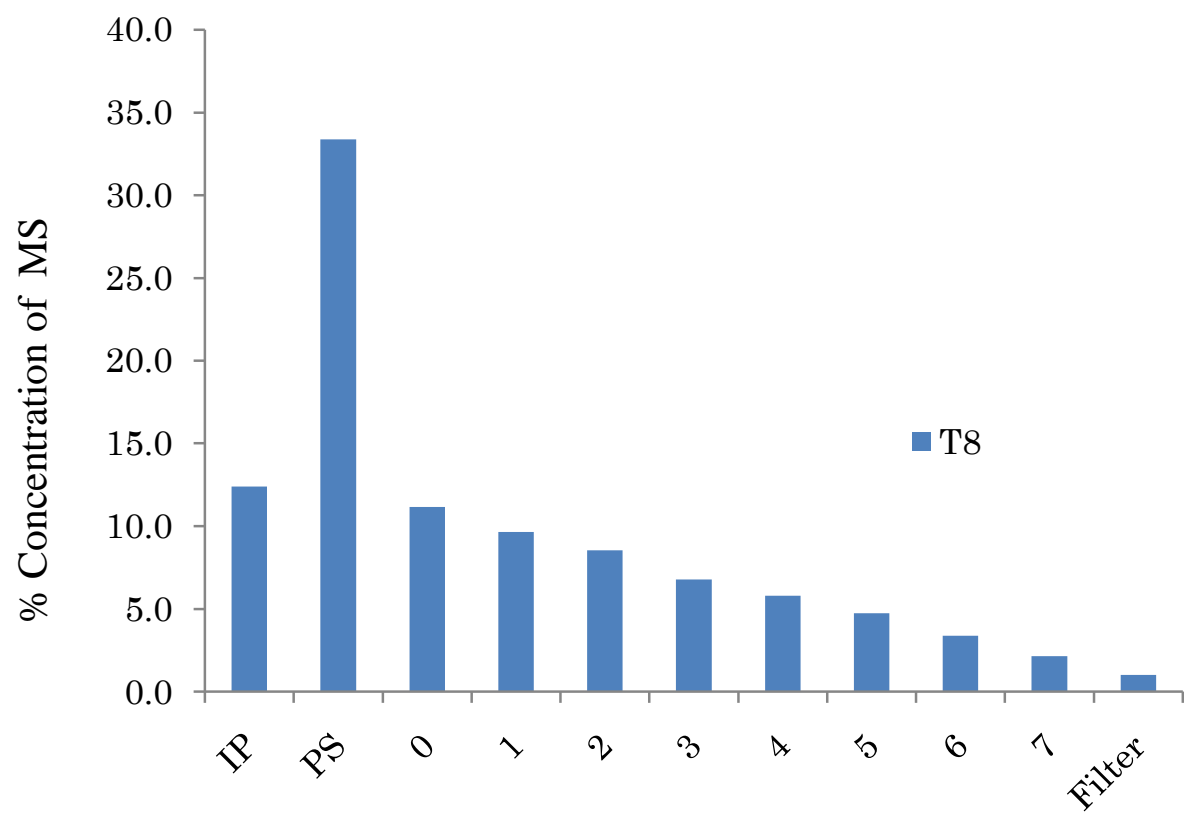

Stages of ACI

Fig. 29. ACI for \% deposition profiles in each stage for formulation T8 


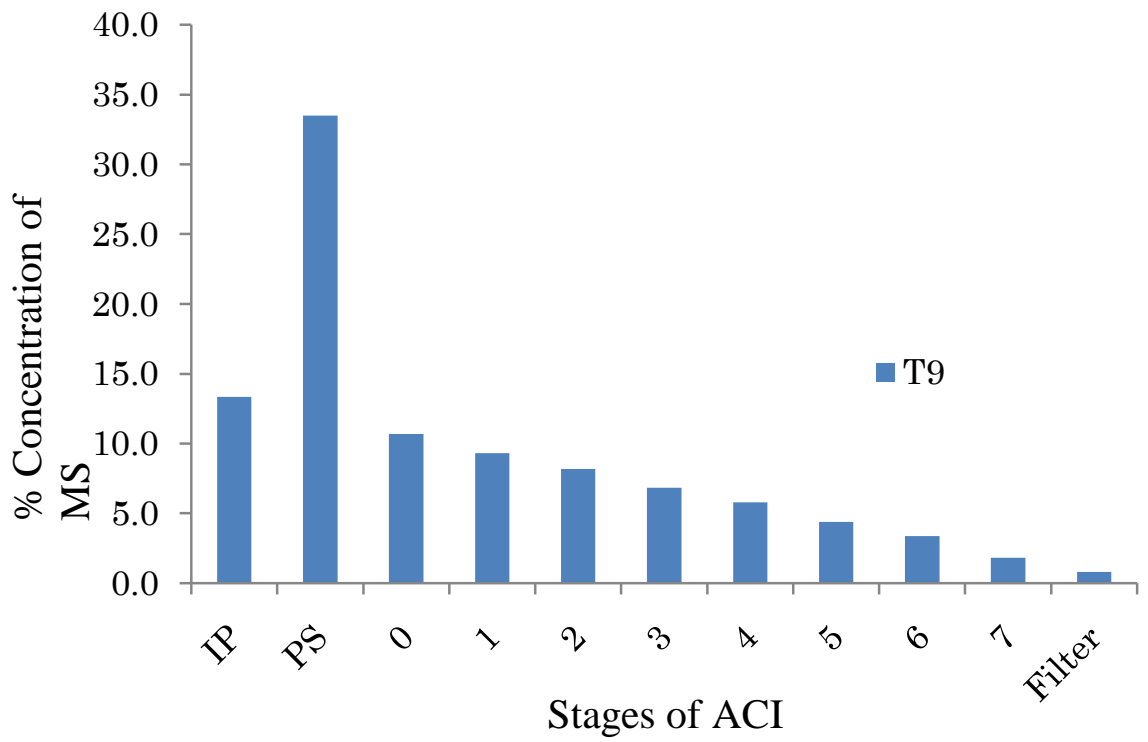

Fig. 30. ACl for \% deposition profiles in each stage for formulation T9

Table 6. ACl results for the formulations $\mathrm{T} 1, \mathrm{~T} 2$ and $\mathrm{T} 3$ measured using an air-flow rate of 60

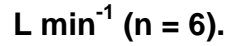

\begin{tabular}{|c|c|c|c|}
\hline \multirow{2}{*}{ Particle size Attributes } & \multicolumn{2}{|c|}{ ACI (inhalation indices) Mean \pm SD } \\
\cline { 2 - 4 } & T1 & T2 & T3 \\
\hline Emitted dose (\%) & $98.8 \pm 2.57$ & $98.2 \pm 2.97$ & $98.2 \pm 2.96$ \\
\hline Respiratory fraction $(\%)$ & $34.9 \pm 2.59$ & $33.7 \pm 3.08$ & $33.1 \pm 2.93$ \\
\hline Total recovery & $99.8 \pm 3.02$ & $98.9 \pm 3.37$ & $98.9 \pm 2.96$ \\
\hline Mean median aerodynamic diameter $(\mu \mathrm{m})$ & $1.75 \pm 0.11$ & $1.94 \pm 0.12$ & $2.14 \pm 0.21$ \\
\hline
\end{tabular}

Table 7. ACl results for the formulations T4, T5 and T6 measured using an air-flow rate of $60 \mathrm{~L} \mathrm{~min}^{-1}(\mathrm{n}=6)$.

\begin{tabular}{|l|c|c|c|}
\hline \multirow{2}{*}{ Particle size Attributes } & \multicolumn{3}{|c|}{ ACl (inhalation indices) Mean \pm SD } \\
\cline { 2 - 4 } & T4 & T5 & T6 \\
\hline Emitted dose (\%) & $98.5 \pm 2.39$ & $96.8 \pm 2.8$ & $96.9 \pm 2.87$ \\
\hline Respiratory fraction (\%) & $34.5 \pm 2.17$ & $32.2 \pm 2.8$ & $31.9 \pm 2.70$ \\
\hline Total recovery & $99.5 \pm 2.82$ & $97.8 \pm 3.1$ & $97.9 \pm 3.16$ \\
\hline Mean median aerodynamic diameter $(\mu \mathrm{m})$ & $1.72 \pm 0.3$ & $1.90 \pm 0.20$ & $2.24 \pm 0.01$ \\
\hline
\end{tabular}

Table 8. ACI results for the formulations T7, T8 and T9 measured using an air-flow rate of $60 \mathrm{~L} \mathrm{~min}^{-1}(\mathrm{n}=6)$.

\begin{tabular}{|c|c|c|c|}
\hline \multirow{2}{*}{ Particle size Attributes } & \multicolumn{2}{|c|}{ ACI (inhalation indices) Mean \pm SD } \\
\cline { 2 - 4 } & T7 & T8 & T9 \\
\hline Emitted dose (\%) & $97.6 \pm 3.09$ & $97.9 \pm 3.1$ & $97.2 \pm 3.04$ \\
\hline Respiratory fraction $(\%)$ & $33.8 \pm 2.84$ & $32.4 \pm 2.65$ & $31.2 \pm 2.67$ \\
\hline Total recovery & $98.6 \pm 3.47$ & $98.9 \pm 3.45$ & $98.2 \pm 3.38$ \\
\hline Mean median aerodynamic diameter $(\mu \mathrm{m})$ & $1.71 \pm 0.10$ & $1.89 \pm 0.3$ & $2.14 \pm 0.11$ \\
\hline
\end{tabular}

\section{The in vitro drug dissolution:}

The dissolution was carried out in PBS at $\mathrm{pH} 7.4$ at $37^{\circ} \pm 0.5^{\circ} \mathrm{C}$. The drug released at $12 \mathrm{~h}$ of formulation trials were T1, $91.23 \%$; T2, 86.92\%; T3, 85.05\%; T4, 90.67; T5, 85.27\%; T6, 84.05; T7,90.56; T8,86.91 and T9,83.67. The drug releases were found to be not less than $80 \%$ at $12 \mathrm{~h}$ in all trials. The Fig. $31-33$ represents cumulative percent drug release 
versus time in hours for formulations T1-T9. It was understood that the drug release versus time proved the sustained release of drugs in all formulations T1-T9. SS:PLGA(50:50) Formulation T1 exhibited best dissolution result, when compared to other formulations T2-T9 [50].

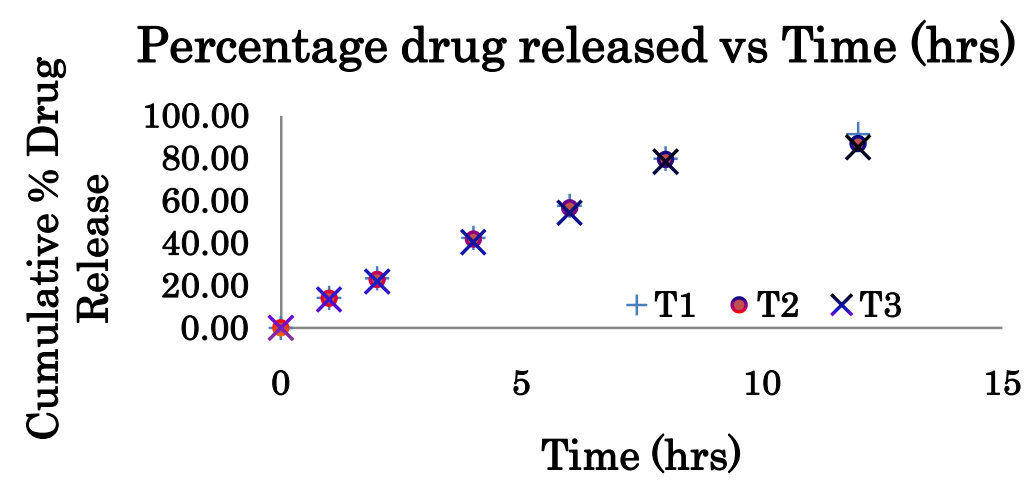

Fig. 31. Cumulative Percent drug release versus time (h) for formulations T1-T3 $(n=3)$.

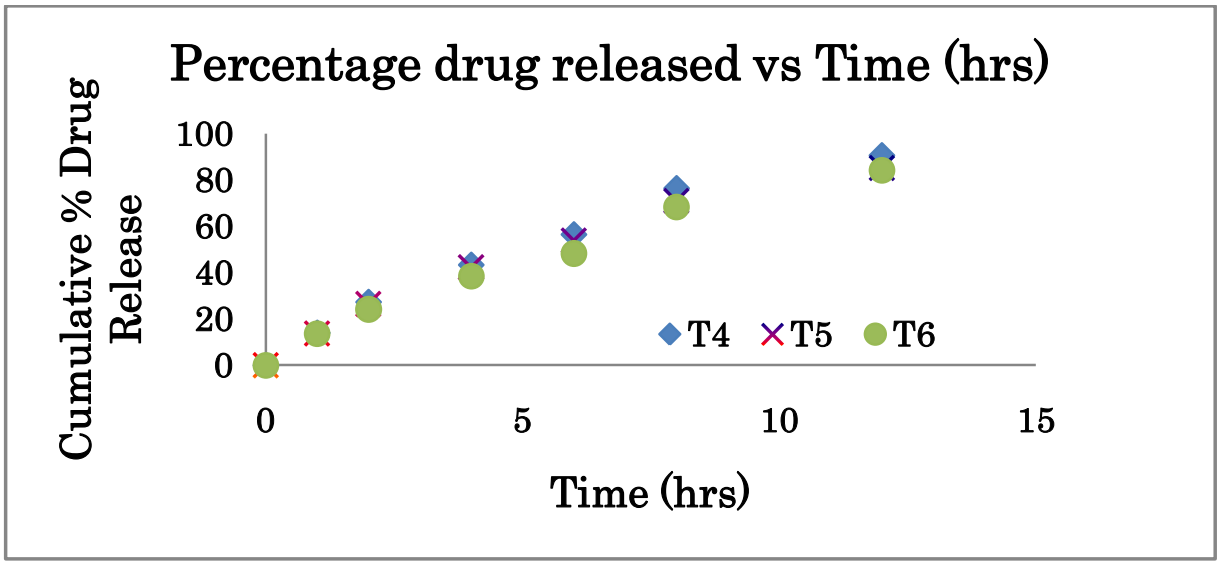

Fig. 32. Cumulative Percent drug release versus time $(h)$ for formulations T4-T6 $(n=3)$.

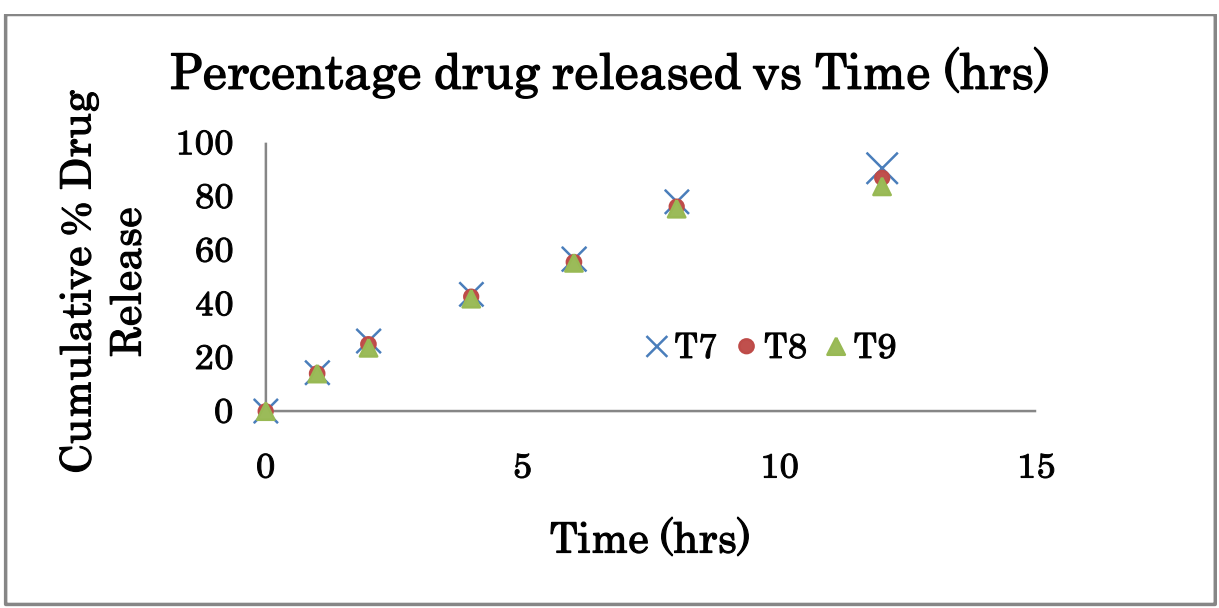

Fig. 33. Cumulative Percent drug release versus time $(h)$ for formulation trials T7-T9 $(n=3)$.

\section{Antibacterial activity:}

The antibacterial activity of the dry powder inhaler formulation trials T1-T9 were studied against gram positive, gram negative bacteria and fungi shown in Table 9. The three respiratory drugs were found demonstrated antibacterial activity. The minimum inhibitory concentrations were determined. Significant antimicrobial activity was found with the dry powder inhaler formulation. The microparticle possess a notable antibacterial action against all the microorganisms were tested. 
Table 9. Minimum inhibitory $(\mathrm{mm})$ concentration of the microorganism for Trial T1 - T9

\begin{tabular}{|c|c|c|c|c|c|}
\hline \multirow[t]{2}{*}{ Test Micro organisms } & \multicolumn{5}{|c|}{ Zone of inhibition (mm) } \\
\hline & Sample & $250 \mu \mathrm{g} / \mathrm{ml}$ & $500 \mu \mathrm{g} / \mathrm{ml}$ & $1 \mathrm{mg} / \mathrm{ml}$ & Standard $^{\star}$ \\
\hline \multirow{9}{*}{$\begin{array}{l}\text { Staphylococcus aureus } \\
\text { (Gram positive) }\end{array}$} & T1 & 5 & 7 & 10 & 19 \\
\hline & T2 & 6 & 6 & 10 & 18 \\
\hline & T3 & 6 & 6 & 9 & 17 \\
\hline & T4 & 6 & 8 & 10 & 20 \\
\hline & T5 & 5 & 6 & 10 & 19 \\
\hline & T6 & 6 & 7 & 8 & 20 \\
\hline & T7 & 7 & 7 & 9 & 21 \\
\hline & T8 & 6 & 8 & 8 & 20 \\
\hline & T9 & 7 & 7 & 8 & 20 \\
\hline \multirow{9}{*}{$\begin{array}{l}\text { Micrococcus luteus } \\
\text { (Gram positive) }\end{array}$} & T1 & 7 & 8 & 11 & 20 \\
\hline & T2 & 6 & 7 & 10 & 20 \\
\hline & T3 & 6 & 6 & 9 & 19 \\
\hline & T4 & 5 & 9 & 10 & 21 \\
\hline & T5 & 5 & 8 & 11 & 19 \\
\hline & T6 & 5 & 7 & 10 & 20 \\
\hline & T7 & 6 & 7 & 10 & 19 \\
\hline & T8 & 6 & 6 & 9 & 18 \\
\hline & T9 & 6 & 6 & 10 & 17 \\
\hline \multirow{9}{*}{$\begin{array}{c}\text { Escherichia coli (Gram } \\
\text { negative) }\end{array}$} & $\mathrm{T} 1$ & 6 & 9 & 10 & 20 \\
\hline & T2 & 6 & 7 & 10 & 20 \\
\hline & T3 & 5 & 8 & 9 & 19 \\
\hline & T4 & 7 & 8 & 9 & 21 \\
\hline & T5 & 6 & 7 & 8 & 20 \\
\hline & T6 & 6 & 7 & 9 & 19 \\
\hline & $\mathrm{T} 7$ & 5 & 7 & 11 & 20 \\
\hline & T8 & 4 & 8 & 10 & 19 \\
\hline & T9 & 5 & 7 & 10 & 20 \\
\hline \multirow{9}{*}{$\begin{array}{c}\text { Pseudomonas } \\
\text { aeruginosa (Gram } \\
\text { negative) }\end{array}$} & $\mathrm{T} 1$ & 6 & 9 & 9 & 21 \\
\hline & T2 & 5 & 7 & 9 & 20 \\
\hline & T3 & 5 & 7 & 8 & 20 \\
\hline & T4 & 6 & 8 & 10 & 20 \\
\hline & T5 & 5 & 8 & 9 & 19 \\
\hline & T6 & 6 & 7 & 10 & 19 \\
\hline & $\mathrm{T} 7$ & 7 & 8 & 11 & 19 \\
\hline & T8 & 6 & 6 & 10 & 18 \\
\hline & T9 & 7 & 7 & 10 & 18 \\
\hline
\end{tabular}




\begin{tabular}{|l|l|l|l|l|l|}
\hline Aspergillus niger (Fungi) & T1 & 7 & 7 & 10 & 20 \\
& T2 & 7 & 7 & 9 & 20 \\
& T3 & 6 & 6 & 10 & 19 \\
& T4 & 5 & 8 & 9 & 19 \\
& T5 & 5 & 7 & 9 & 18 \\
& T6 & 4 & 7 & 9 & 18 \\
& T7 & 6 & 7 & 11 & 20 \\
& T8 & 5 & 6 & 10 & 19 \\
& T9 & 4 & 6 & 11 & 19 \\
\hline
\end{tabular}

*Standard - ciprofloxacin

\section{MTT assay:}

The sustained release microparticles tested for by cell line studies. The Invitro cell viability assayed (MTT assay) carried out by alveolar epithelial cancer cell line A549 for formulations T1-T9. MTT assay is a colorimetric method for measuring the activity of enzymes in living cells that reduce MTT to formazan dyes, giving a purple color. The process of MTT assay given in table 8 . It is commonly used to determine cytotoxicity of potential medicinal agents and toxic materials, since these types of materials are expected to stimulate or inhibit cell viability and growth. At $500 \mu \mathrm{g}$ concentration, formulations T1-T9 showed more than $80 \%$ cell viability. The results indicated that the formulations are safe proved with alveolar epithelial cancer cell line A549 by invitro cell viability assay. Percentage of cell viability graph of T1-T9 was presented in Fig. 34.

Calculated the cell density and percentage cell viability using the following formula

Calculated the average cell density of triplicates:

\section{Optical density of sample}

Percentage of cell viability $(\%) \quad=$

Optical density of Control

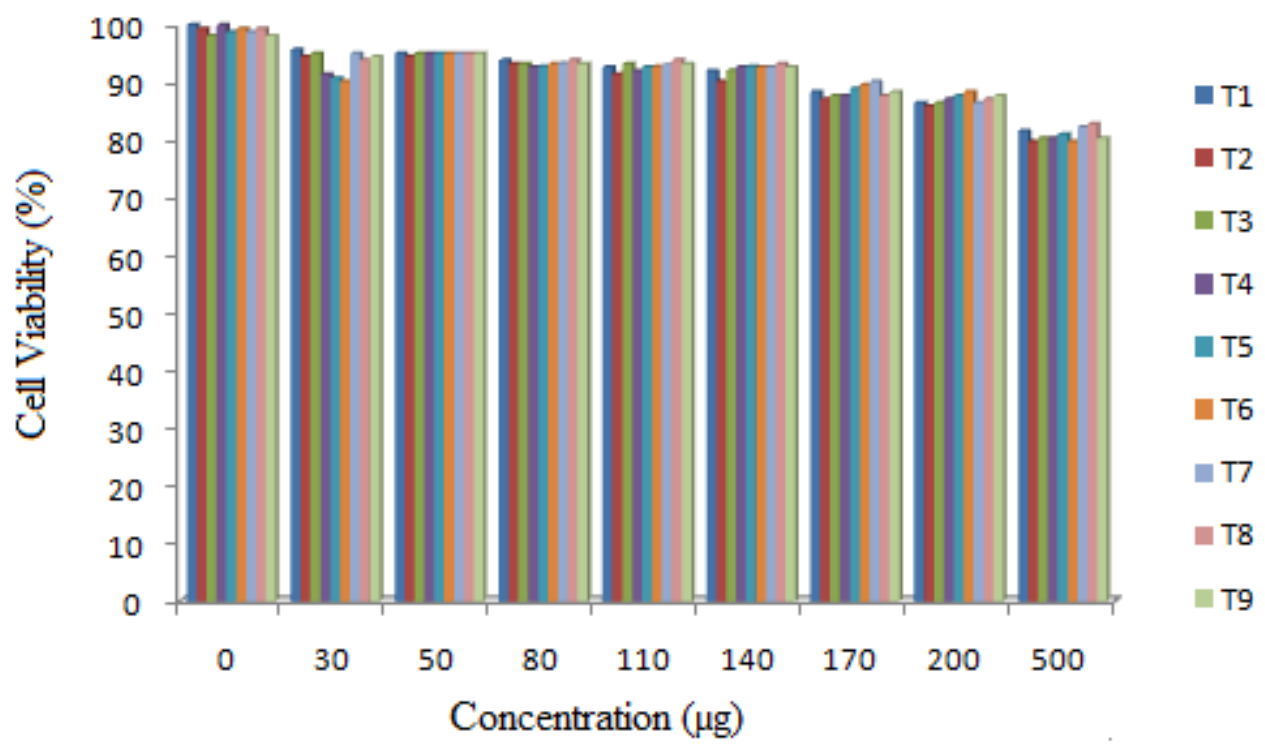

Fig. 34. Percentage cell viability against alveolar epithelial cancer cell line A549 of formulated DPI; Data are presented as mean $\pm \mathrm{SD}, n=3$.

\section{CONCLUSION}

The orally inhalable dry powder formulation was prepared using drug and polymers for encapsulation. The prepared 


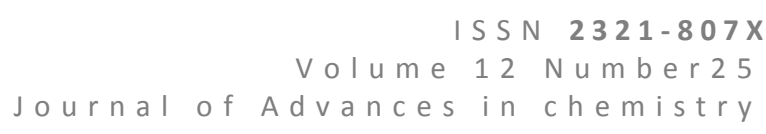

microparticles committed for sustained drug delivery in airways through inhalation. All the formulations had extended in vitro drug release profile upto 12 hours. Formulation T1 compared with all the nine formulations based on laboratory analysis was best. In vitro drug deposition studies exhibit optimum characteristics of respirable particles. Further invivo studies will be carried out to analyse clinical characteristics of formulations.

\section{ACKNOWLEDGMENTS}

The author's express sincere thanks to SAIF, IIT, Madras - 600025, TN, India.

\section{REFERENCES}

1. Tristan, PL, Jane, LB, Eddie, F and Peter Seville C. 2008. Chitosan based spray dried respirable powders for sustained delivery of terbutaline sulfate, European Journal of Pharmaceutics and Biopharmaceutics, Vol.68, No.2, 224-234.

2. Rasenack, N, and Muller BW. 2004. Micron-size drug particles: common and novel micronization techniques, Pharm. Dev. Technol., Vol.9, No.1, 1-13.

3. Larhrib, H, Martin, GP, Marriott C, and Prime D. 2003. The influence of carrier and drug morphology on drug delivery from dry powder formulations, Vol.257, No.1, 283-296.

4. Bosquillon, C, Preat, V, and Vanbever R. 2004. Pulmonary delivery of growth hormone using dry powders and visualization of its local fate in rats. J. Control. Release, Vol.96,

No.2, 233-244.

5. Rabbani, NR, and Seville PC. 2005. The influence of formulation components on the aerosolisation properties of spray dried powders. J. Control.Release, Vol.110, No.1, 130-140.

6. Cook, RO, Pannu, RK, and Kellaway IW. 2005. Novel sustained release microspheres for pulmonary drug delivery. J.Control. Release, Vol.104, No.1, 79-90.

7. Steckel, H, Markefka, P, Tewierik H, and Kammelar R. 2006. Effect of milling and sieving on functionality of dry powder inhalation products. Int J Pharm., Vol.309, No.1, 51-9.

8. Rasenack, N, Steckel, H, and Muller BW. 2003. Micronization of anti-inflammatory drugs for pulmonary delivery by a controlled crystallization process. J. Pharm. Sci., Vol.92, No.1, 35-44.

9. Kyrre, T, David, L, and Anders A. 2004. Comparison of different flowability tests for powders for inhalation. Powder Technology, Vol.146, No.3, 206-213.

10. Chan HK. 2008. What is the role of particle morphology in pharmaceutical powder aerosols. Expert Opinion on Drug Delivery, Vol.5, No.8, 909-914.

11. Son, YJ, and Mcconville JT. 2009. Development of a standardized dissolution test method for inhaled pharmaceutical formulations. International Journal of Pharmaceutics, Vol.382, No.1, 15-22.

12. Louey, MD, Van Oort, M, and Hickey AJ. 2004. Aerosol dispersion of respirable particles in narrow size distributions using drug-alone and lactose-blend formulations. Pharmaceutical Research, Vol.21, No.7, 1207-1213.

13. Adi, H, Traini, D, Chan, HK, and Young PM. 2008. The influence of drug morphology on the aerosolisation efficiency of dry powder inhaler formulations. Journal of Pharmaceutical Sciences, Vol.97, No.7, 2780-2788.

14. Chew, NYK, Chan, HK, Bagster, DF, and Mukhraiya J. 2002. Characterization of pharmaceutical powder inhalers:estimation of energy input for powder dispersion and effect of capsule device configuration. Journal of Aerosol Science, Vol.33, No.7, 999-1008.

15. Henwood, SQ, Devilliers, MM, Liebenberg, W, and Lotter AP. 2000. Solubility and dissolution properties of generic rifampicin raw materials. Drug Development and Industrial Pharmacy, Vol.26, No.4,403-408.

16. Panchagnula, R, and Bhardwaj V. 2008. Effect of amorphous content on dissolution characteristics of rifampicin. Drug Development and Industrial Pharmacy, Vol.34, No.6, 642-649.

17. Nashwa, EG, and Cory B. 2009. Combination chemotherapeutic dry powder aerosols via controlled nanoparticle agglomeration. Pharmaceutical Research, Vol.26, No.7, 1752-63.

18. Taylor, MK, Hickey, AJ, and Vanoort M. 2006. Manufacture, characterization, and pharmacodynamic evaluation of engineered ipratropium bromide particles. Pharm. Dev. Technol., Vol.11, No.3,321-336.

19. Gavini, E, Hegge, AB, Rassu, G, Sanna, V, Testa, C, Pirisino, G, Karlsen, J, and Giunchedi P. 2006. Nasal administration of carbamazepine using chitosan microspheres: in vitro/in vivo studies. Int. J. Pharm., Vol.307, No.1, 9-15.

20. Huang, YC, Yeh, MK, Cheng, SN, and Chiang CH. 2003. The characteristics of betamethasone-loaded chitosan microparticles by spraydrying method. J. Microencapsul., Vol.20, No.4, 459-472. 
21. Grenha, A, Seijo, B, and Remunan Lopez C.2005. Microencapsulated chitosan nanoparticles for lung protein delivery. Eur. J. Pharm. Sci., Vol. 25, No.4, 427-437.

22. Huang, YC, Vieira, A, Huang, KL, Yeh, MK, and Chiang $\mathrm{CH}$. 2005. Pulmonary inflammation caused by chitosan microparticles. J.Biomed. Mater. Res., A. Vol.75, No.2, 283-287.

23. Lee, HJ, Joung, SK, Kim, YG, Yoo, JY, and Han SB. 2004. Bioequivalence assessment of ambroxol tablet after a single oral dose administration to healthy male volunteers. Pharm Research, Vol.49, No.3, 93-98.

24. Newman, SP, and Busse WW. 2002. Evolution of dry powder inhaler design, formulation, and performance. Respir Med., Vol.96, No.5, 293-304.

25. Schiavone, H, Palakodaty, S, Clark, A, York, P, and Tzannis ST. 2004. Evaluation of SCF-engineered particle-based lactose blends in passive dry powder inhalers. Int. J.Pharm., Vol.281, No.1, 55- 66.

26. Chew, NYK, Tang, P, and Chan HK. 2005. How much particle surface corrugation is sufficient to improve aerosol performance of powders. Pharm Research, Vol.22, No.1,148-52.

27. Mitchell, JP, and Nagel MW. 2003. Cascade impactors for the size characterizationof aerosols from medical inhalers: their uses and limitations. J Aerosol Med., Vol.16, No.4, 341-377.

28. Vermehren, C, Frokjaer, S, and Aurstad T. 2006. Lung surfactant as a drug delivery system. Int J Pharm., Vol.307, No.1, 89-92.

29. Moiz, MD, Prathima, SM, and Sadanandam M. 2011. Formulation and evaluation of bilayered tablets of montelukast and levocetrizine dihydrochloride using natural and synthetic polymers. International journal of drug delivery, Vol.3, No.4, 597-618.

30. Harivardhanreddy, L, and Murthy RS. 2005. Etoposide-loaded nanoparticles made from glyceride lipids: Formulation, characterization, in vitro drug release and stability evaluation. AAPS Pharm Sci Tech., Vol.6, No.2, E158-166.

31. Nutan, S,Manish, K, Rohit, S and Vishal S. 2011. Sustained release of spray dried combination dry powder inhaler formulation for pulmonary delivery. Asian J Pharm Clin Res., Vol.4, No.4,112-118.

32. Learoyd, T, Burrows, J, Frenchc, E, and Seville P. 2009. Sustained delivery by Leucine modified chitosan spray dried respirable powders. Int. J. Pharm, Vol.372, No.1,97-104.

33. Seville, P, and Rabbani N. 2005. The influence of formulation components on the aerosolization properties of spray dried powders. J. Controlled Release, Vol.110, No.1,130-140.

34. Steckel, H, and Brandes HG. 2004. A novel spray-drying technique to produce low density particles for pulmonary delivery. Int J Pharm., Vol. 278, No.1, 187-95.

35. Panchal, R, Patel, H, Patel, V, Joshi, P, and Parikh A. 2012. Formulation and evalution of montelukast sodium chitosan based spray dried microspheres for pulmonary drug delivery.

J Pharm Bioall Sci., Vol.4, No.1, 110-14.

36. Steve, RM, Martin, JD, and Hugh DCS. 2011. Effects of mild processing pressures on the performance of dry powder inhaler formulations for inhalation therapy: Budesonide and lactose. European Journal of Pharmaceutics and Biopharmaceutics, Vol.78, No.1, 97-106.

37. Larhrib, H, Martin, GP, Marriott, C, and Prime D. 2003. The influence of carrier and drug morphology on drug delivery from dry powder formulations. Int J Pharm., Vol.257, No.1, 283-296.

38. Cook, RO, Pannu, RK, and Kellaway IW. 2005. Novel sustained release microspheres for pulmonary drug delivery. J.Control Rel., Vol.104, No.1,79-90.

39. Li, HY, Birchall J. 2006. Chitosan-modified dry powder formulations for pulmonary gene delivery. Pharm Res., Vol.23, No.5, 941-950.

40. Kamrun, N, Nilesh, G, Robert, G, Shahriar, A, Brijeshkumar, P, Vivek, G, Ali, K, and Fakhrul A. 2013. In-vitro, in-vivo and ex-vivo models for studying particle deposition and drug absorption of inhaled pharmaceuticals. European Journal of Pharmaceutical Sciences, Vol.49, No.5,805-818. 
41. Al,QS, Grenha, A, Carrion, RD, Seijo, B abd Remunan LC.2012.Microencapsulated chitosan nanoparticles for pulmonary protein delivery:in vivo evaluation of insulin loaded formulations. J.Control.Release, Vol.157, No.3, 383-390.

42. Ramalingam, S, and Belani CP. 2007. Recent advances in targeted therapy for nonsmall cell lung cancer. Expert Opin. Ther. Targets, Vol.11, No.2, 245-257.

43. Taki, M, Marriott, C, Zeng, XM, and Martin GP. 2010. Aerodynamic deposition of combination dry powder inhaler formulations in vitro: a comparison of three impactors. Int. J.Pharm., Vol.388, No.1,40-51.

44. Chan, HK, Young, PM, Traini, D, and Coates M. 2007. Dry powder inhalers: challenges and goals for next generation therapies. Pharm.Technol. Eur., Vol.19, No.4,19-24.

45. Wallace, PA, David, C, Douglas, SL, Beth M, Ziqing P, Gurjaipallsingh, Yi Tsong, and Svetlana L. 2007. Product Quality research institute evaluation of cascade impactor profiles of pharmaceutical aerosols, Part 1:Background for a Statistical Method. AAPS PharmSciTech., Vol.8, No.1, E1- E6.

46. Steve Newman, Hak-Kim Chan, and Jolyon Mitchell. 2007. In Vitro and In Vivo Aspects of Cascade Impactor Tests and Inhaler Performance: A Review. AAPS PharmSciTech., Vol.8, No.4, E1-E9

47. Wasana, C, Wim, EH, and Siriporn O. 2009. Preparation and Characterization of Cephalexin Loaded PLGA microspheres. Current Drug Delivery, Vol.6, No.1, 69-75

48. Parikh, RH, Parikh, JR, Dubey, RR, Soni, HN, and Kapadia KN. 2003.

Poly(d,I-lactide-co-glycolide) microspheres containing 5-fluorouracil: optimization of process parameter. AAPS PharmSci.Tech, Vol.4, No.2,14-21.

49. Fu, X, Ping, Q, and Gao Y. 2005. Effect of formulation factors on encapsulation efficiency and release behaviour in vitro of hyperzine PLGA microspheres. J. Microencapsulation, Vol.22, No.7, 705-14.

50. Peltonen, L, Koistinen, P, Karjalainen, M, Haekkinen, A, and Hirvonen J. 2002. The effect of cosolvents on the formation of nanoparticle from low molecular weight poly(I)lactide. AAPS Pharm. Sci. Technol, Vol. 3, No.4,1-7.

\section{Author' biography with Photo}

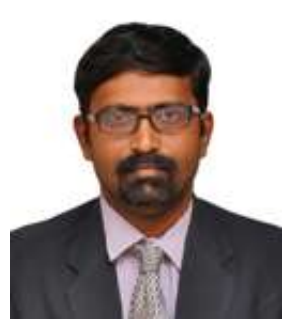

Dr.K.Sathish Kumar, Associate Professor in the Department of Chemical Engineering, SSN College of engineering, Kalavakkam-603110. He has 14 years of teaching and research experience, including 4 years of research experience in the field of nanoparticle synthesis for drug delivery applications. He received his B.Tech (Chem) degree first class from Madras University, M.Tech.(Chem) first class with distinction from the Bharathiar University, Coimbatore and PhD from Anna University Chennai. 